\title{
Land use is the main driver of soil organic carbon spatial distribution in a high mountain ecosystem
}

\author{
Carmine Fusaro ${ }^{1}$, Yohanna Sarria-Guzmán ${ }^{2}$, Yosef A Chávez-Romero ${ }^{3}$, Marco Luna-Guido ${ }^{3}$, Ligia C Muñoz-Arenas \\ ${ }^{1}$, Luc Dendooven ${ }^{3}$, Arturo Estrada-Torres ${ }^{4}$, Yendi E Navarro-Noya ${ }^{\text {Corresp. } 5}$ \\ ${ }^{1}$ Doctorado en Ciencias Biológicas, Centro Tlaxcala de Biología de la Conducta, Universidad Autónoma de Tlaxcala, Tlaxcala, Tlaxcala, Mexico \\ 2 Grupo de Investigación en Nutrición y Dietética, Universidad del Sinú, Cartagena de Indias, Colombia \\ 3 Biotechnology and Bioengineering, Centro de Investigación y de Estudios Avanzados del Instituto Politécnico Nacional, Ciudad de México, Mexico \\ 4 Centro Tlaxcala de Biología de la Conducta, Universidad Autónoma de Tlaxcala, Tlaxcala, Tlaxcala, Mexico \\ ${ }^{5}$ Cátedras Conacyt, Universidad Autónoma de Tlaxcala, Tlaxcala, Tlaxcala, Mexico \\ Corresponding Author: Yendi E Navarro-Noya \\ Email address: yenavarrono@conacyt.mx
}

Background. Terrestrial ecosystems play a significant role in carbon (C) storage. Human activities, such as urbanization, infrastructure, and land use change, can reduce significantly the $C$ stored in the soil. The aim of this research was to measure the spatial variability of soil organic C (SOC) in the national park La Malinche (NPLM) in the central highlands of Mexico as an example of highland ecosystems and to determine the impact of land use change on the SOC stocks through deterministic and geostatistical geographic information system (GIS) based methods. Methods. The soil was collected from different landscapes, i.e. pine, fir, oak and mixed forests, natural grassland, moor and arable land, and organic C content determined. Different GIS-based deterministic (inverse distance weighting, local polynomial interpolation and radial basis function) and geostatistical interpolation techniques (ordinary kriging, cokriging and empirical Bayes kriging) were used to map the SOC stocks and other environmental variables of the top soil layer.

Results. All interpolation GIS-based methods described the spatial distribution of SOC of the NPLM satisfactorily. The total SOC stock of the NPLM was $2.45 \mathrm{Tg} C$ with $85.3 \%$ in the forest (1.26 Tg C in the A horizon and $0.83 \mathrm{Tg} C$ in the $O$ horizon), $11.4 \%$ in the arable soil (0.23 Tg in the A horizon and only $0.05 \mathrm{Tg} C$ in the $O$ horizon) and 3.3\% in the high moor (0.07 Tg $C$ in the A horizon and $<0.01 \mathrm{Tg} C$ in the $O$ horizon). The estimated total SOC stock in a preserved part of the forest in NPLM was $4.98 \mathrm{Tg} \mathrm{C}$ in 1938 and has nearly halved since then. Continuing this trend of converting all the remaining forest to arable land will decrease the total SOC stock to $0.52 \mathrm{Tg}$ C. Discussion. Different factors explain the large variations in SOC stocks found in this study but the change in land use (conversion of forests into agricultural lands) was the major reason for the reduction of the SOC stocks in the high mountain ecosystem of the NPLM. Large amounts of $C$, however, 
could be stored potentially in this ecosystem if the area was used more sustainable. The information derived from this study could be used to recommend strategies to reverse the SOC loss in NPLM and other high-altitude temperate forests and sequester larger quantities of $\mathrm{C}$. This research can serve as a reference for the analysis of SOC distribution in similar mountain ecosystems in central part of Mexico and in other parts of the world. 
1 Land use is the main driver of soil organic carbon spatial distribution in a high mountain

2 ecosystem

3

4 Carmine Fusaro ${ }^{1}$, Yohanna Sarria-Guzmán², Yosef A. Chávez-Romero ${ }^{3}$, Marco Luna-Guido ${ }^{3}$,

5 Ligia C. Muñoz-Arenas ${ }^{1}$, Luc Dendooven ${ }^{3}$, Arturo Estrada-Torres ${ }^{4}$, Yendi E. Navarro-Noya ${ }^{5}$

6

$7 \quad{ }^{1}$ Doctorado en Ciencias Biológicas, Centro Tlaxcala de Biología de la Conducta, Universidad

8 Autónoma de Tlaxcala, Tlaxcala, Mexico

$9{ }^{2}$ Grupo de Investigación en Nutrición y Dietética, Universidad del Sinú, Cartagena de Indias,

10 Colombia

$11{ }^{3}$ Biotechnology and Bioengineering, Centro de Investigación y de Estudios Avanzados del

12 Instituto Politécnico Nacional, Ciudad de México, Mexico

$13{ }^{4}$ Centro Tlaxcala de Biología de la Conducta, Universidad Autónoma de Tlaxcala, Tlaxcala,

14 Mexico

$15{ }^{5}$ Cátedras Conacyt -Universidad Autónoma de Tlaxcala, Tlaxcala, Mexico

16

17 Corresponding Author:

18 Yendi E. Navarro-Noya, nyendi@hotmail.com; yenavarrono@conacyt.mx 


\section{ABSTRACT}

21 Background. Terrestrial ecosystems play a significant role in carbon (C) storage. Human

22 activities, such as urbanization, infrastructure, and land use change, can reduce significantly the

$23 \mathrm{C}$ stored in the soil. The aim of this research was to measure the spatial variability of soil organic

$24 \mathrm{C}$ (SOC) in the national park La Malinche (NPLM) in the central highlands of Mexico as an 25 example of highland ecosystems and to determine the impact of land use change on the SOC 26 stocks through deterministic and geostatistical geographic information system (GIS) based 27 methods.

28 Methods. The soil was collected from different landscapes, i.e. pine, fir, oak and mixed forests, 29 natural grassland, moor and arable land, and organic C content determined. Different GIS-based 30 deterministic (inverse distance weighting, local polynomial interpolation and radial basis 31 function) and geostatistical interpolation techniques (ordinary kriging, cokriging and empirical 32 Bayes kriging) were used to map the SOC stocks and other environmental variables of the top 33 soil layer.

Results. All interpolation GIS-based methods described the spatial distribution of SOC of the 35 NPLM satisfactorily. The total SOC stock of the NPLM was $2.45 \mathrm{Tg} \mathrm{C}$ with $85.3 \%$ in the forest 36 (1.26 $\mathrm{Tg} \mathrm{C}$ in the A horizon and $0.83 \mathrm{Tg} \mathrm{C}$ in the $\mathrm{O}$ horizon), $11.4 \%$ in the arable soil $(0.23 \mathrm{Tg}$ in 37 the A horizon and only $0.05 \mathrm{Tg} \mathrm{C}$ in the $\mathrm{O}$ horizon) and $3.3 \%$ in the high moor $(0.07 \mathrm{Tg} \mathrm{C}$ in the 38 A horizon and $<0.01 \mathrm{Tg} \mathrm{C}$ in the $\mathrm{O}$ horizon). The estimated total SOC stock in a preserved part 39 of the forest in NPLM was $4.98 \mathrm{Tg} \mathrm{C}$ in 1938 and has nearly halved since then. Continuing this 40 trend of converting all the remaining forest to arable land will decrease the total SOC stock to $410.52 \mathrm{Tg}$ C. 
42 Discussion. Different factors explain the large variations in SOC stocks found in this study but 43 the change in land use (conversion of forests into agricultural lands) was the major reason for the 44 reduction of the SOC stocks in the high mountain ecosystem of the NPLM. Large amounts of C, 45 however, could be stored potentially in this ecosystem if the area was used more sustainable. The 46 information derived from this study could be used to recommend strategies to reverse the SOC 47 loss in NPLM and other high-altitude temperate forests and sequester larger quantities of C. This 48 research can serve as a reference for the analysis of SOC distribution in similar mountain 49 ecosystems in central part of Mexico and in other parts of the world.

50

51 Keywords Arable land; Climate change; Deterministic interpolation; Forest soil; Geostatistical 52 interpolation; High altitude temperate forest 


\section{INTRODUCTION}

55 Climate change is arguably one of the most important environmental challenges of the $21^{\text {st }}$ century (Roose et al., 2005; Gerber et al., 2013; Feulner, 2017). Climate change and global warming will affect humanity, as rising temperatures will change weather patterns with more extreme natural events. These will cause serious damage to infrastructure and ecosystems and affect crop production, and have a strong and enduring social, economic and environmental impact (FAO, 2008; Dodo, 2014; Gobiet et al., 2014).

Human activities, such as fossil fuel burning, raising livestock, land use change and agriculture increases greenhouse gas (GHG) emissions (Stocker, 2014). These anthropogenic activities are the main reason for the increase of GHG in the atmosphere, i.e. mostly carbon dioxide $\left(\mathrm{CO}_{2}\right)$, methane $\left(\mathrm{CH}_{4}\right)$ and nitrous oxide $\left(\mathrm{N}_{2} \mathrm{O}\right)$, which leads to the greenhouse effect and global warming (Roose et al., 2005; Steinfeld et al., 2006; Reddy, 2015).

Atmospheric $\mathrm{CO}_{2}$ concentrations can be lowered either by reducing emissions derived from human activities or by sequestering carbon, i.e. taking $\mathrm{CO}_{2}$ out of the atmosphere and storing in organic material of terrestrial, oceanic or freshwater aquatic ecosystems (Roose et al., 2005; Lal, 2008). Terrestrial ecosystems play a significant role in C storage in plant biomass and soil organic matter (Scharlemann et al., 2014; Navarrete-Segueda et al., 2018). The amount of organic $\mathrm{C}$ that can be sequestered in these terrestrial ecosystems depends on multiple factors, e.g. soil characteristics, climatic conditions, vegetation and land use (Lal, 2004; Roose et al., 2005; Shah \& Venkatramanan, 2009). Forests play a crucial function in the global C cycle as large amounts of $\mathrm{C}$ can be sequestered in the vegetation and soil (Lal, 2008; Achat et al., 2015; Sedjo, Sohngen \& Riddle, 2015). For instance, the organic C content (SOC) in the $20 \mathrm{~cm}$ top layer of mountain soils can be as high as $115 \mathrm{~g} \mathrm{~kg}^{-1}$, but is often much lower and highly variable (Perry, 
77 Oren \& Hart, 1994; Wei et al., 2008; Zhang et al., 2012; Liu et al., 2014; Zhang et al., 2015;

78 Jeelani et al., 2017). A decrease in SOC in a forest soil is due to a decline in litter input,

79 reduction in density and abundance of vegetation and changes in the distribution of plant roots

80 (Lal, 2004; Jandl et al., 2007). The drive to conserve these ecosystems is mostly science-based,

81 but limited often by socio-economic restrains (Catalán et al., 2017). Human activities, such as

82 land use change for agriculture and husbandry, and ecotourism, compromise ecological

83 conservation (Pèlachs et al., 2017) and can reduce SOC stocks sharply (Houghton \& Nassikas,

84 2018). In particular, conversion of forests to arable land and grassland decreased SOC stocks by

$8520-89 \%$ depending on the region, soil characteristics, environmental factors and vegetation (Guo

$86 \&$ Gifford, 2002; Murty et al., 2002; Xia et al., 2017).

87 The geographic information system (GIS) is a computerized database management system for 88 capture, storage, retrieval, manipulation, analysis and display of spatial data. This enables to

89 visualize, analyse and understand environmental patterns and relationships between ecosystem

90 parameters (Chang, 2015; http://www.esri.com/environment). Different geostatistical GIS-based

91 algorithms have been used to describe and determine the spatial distribution of SOC and to

92 determine landscape or regional SOC stocks in different soil ecosystems (Karydas et al., 2009;

93 Sarmadian et al., 2014; Chen et al., 2015; Chabala, Mulolwa \& Lungu, 2017; Bhunia, Shit \&

94 Maiti, 2018). For instance, Bhunia, Shit \& Maiti (2018) used five interpolation methods, i.e.

95 inverse distance weighting (IDW), local polynomial interpolation (LPI), radial basis function

96 (RBF), ordinary kriging (OK) and empirical Bayes kriging (EBK) to model the spatial

97 distribution of SOC in the area of Medinipur Block (India). Cross-validation showed that the OK

98 technique was the best interpolation method. Three different interpolation techniques, i.e. IDW,

$99 \mathrm{OK}$ and RBF, were used to generate maps of clay content, organic matter, total calcium 
100 carbonate $\left(\mathrm{CaCO}_{3}\right)$ and electric conductivity in the topsoil of an agricultural area close to the

101 town of Archanes (Greece). The IDW was the best interpolation technique to describe the spatial

102 variability of organic matter (Karydas et al., 2009). A good description of spatial variability of

103 SOC provides valuable information for evaluating soil fertility, ecological modeling,

104 environmental prediction, natural resources management, soil restoration, woodland regeneration

105 and precision agriculture (Clay \& Shanahan, 2011).

106 The national park La Malinche (NPLM) is located to the east of Mexico City and covers most

107 of the Malinche or Matlalcuéyatl volcano (Arriaga-Cabrera et al., 2009; Osorio, Haas \&

108 MacMillan, 2011). The volcano is part of the Trans-Mexican Volcanic Belt and is the sixth

109 highest mountain of the country. The vegetation at the NPLM includes pine, fir-pine, oak and

110 mixed forests with natural grassland and moor near the top of the volcano, and agriculture on the

111 lower slopes (SEMARNAT, 2013). Although it is a national park, local people extract wood from

112 the forest and agriculture is expanding, which lead to a sharp drop in the retained organic C. This

113 research aimed to determine the spatial variability of SOC in the mountainous ecosystem of

114 NPLM trough GIS-based methods and to link it to land use. Therefore, the soil was sampled

115 extensively to cover the heterogeneity of the landscapes in NPLM in detail. As such, this

116 research can serve as a reference model for the analysis of SOC distribution in similar

117 ecosystems of the Trans-Mexican Volcanic Belt and provides information how to increase C

118 sequestered in them and other similar high altitude forests in the world. The objectives of this

119 study were i) to compare the six most common extrapolation methods to obtain a satisfactory

120 map of SOC so that we could determine which method was the best for further studies in similar

121 ecosystems, ii) to estimate SOC stocks in a high mountain ecosystem, and iii) to explore the 
122 effects of the land use on spatial distribution of SOC and on SOC stocks in the ecosystem

123 studied.

124

125 MATERIAL AND METHODS

126 Study area

127 La Malinche is an eroded stratovolcano that rises to 4,461 masl cut by deep canyons. The NPLM $128\left(482 \mathrm{~km}^{2}\right)$ covers most of the volcano and is located to the east Mexico City (Latitude $\mathrm{N}$ from $1291^{\circ} 06^{\prime} 51^{\prime \prime}$ to $19^{\circ} 20^{\prime} 58^{\prime \prime}$; Longitude W from $97^{\circ} 55^{\prime} 10^{\prime \prime}$ to $98^{\circ} 09^{\prime} 46^{\prime \prime}$ ) (Figure 1). It is a "Priority 130 Land Region for the Conservation" for its biological diversity (Arriaga-Cabrera et al., 2009; 131 Osorio, Haas \& MacMillan, 2011).

132 The vegetation at NPLM includes: $24.2 \%$ pine, $4.5 \%$ fir-pine, $3.4 \%$ oak and $6.9 \%$ mixed 133 forests, $7.0 \%$ natural grassland and moor, and 53.3\% seasonal agriculture (SEMARNAT, 2013).

134 The spatial distribution of the landscapes was obtained from the National Park Management 135 Program of the "Comisión Nacional de Áreas Naturales Protegidas" (Comisión Nacional de 136 Areas Naturales Protegidas, 2014). The soils in the NPLM are mainly regosols, fluvisols and 137 cambisols (IUSS Working Group, 2015). Luvisol sands and some gleysols are found in lowlands 138 and alluvial cones on the eastern and western side of NPLM.

140 Sampling and soil properties analysis

141 The topographic maps (scale 1:50000) of the "Instituto Nacional de Estadistica y Geografia of

142 Mexico" (INEGI, 2018): E14B33 (act. 2015), E14B34 (act. 2015), E14B43 (act. 2014) and

143 E14B44 (act. 2015) were used for cartography. The altitudinal gradient of NPLM was obtained 
144 from the digital elevation model "Continuo de Elevaciones Mexicano 3.0" (CEM 3.0) with a

145 resolution of $15 \mathrm{~m} \times 15 \mathrm{~m}($ INEGI, 2018).

146 The geographic area of the NPLM was divided into 440 100-ha square grids with the software

147 ArcGis. These grids were used as a preliminary template for soil sampling. The geography of the

148 volcano did not allow to access some areas, e.g. the rock face in the south east part of the

149 national park. The sampling sites were designed to cover the area evenly and to include different 150 soil types and land use, i.e. 163 in arable land, 177 in pine forest, 76 in mixed forests, and 24 in 151 natural grassland and moor soil samples.

152 The soil samples were collected from September to December 2016. Field sampling was done 153 with a permission of the 'Secretaría de Medio Ambiente y Recursos Naturales' (SEMARNAT, 154 Mexico) under the collecting permit SGPA/DGVS/15396/15. In each grid, the O horizon was 155 collected if present and $2 \mathrm{~kg}$ soil from and the A horizon, i.e. from the mineral soil surface to 15 $156 \mathrm{~cm}$. The thickness of O horizon was measured. The NPLM is classified as young volcano. The 157 soils are thin and poorly developed so most of the organic $\mathrm{C}$ is concentrated in the top soil 158 (SEMARNAT, 2013). Therefore, the SOC stocks were calculated considering the O horizon and 159 the $0-15 \mathrm{~cm}$ top soil layer. A cylindrical core cutter (dimensions: height $15 \mathrm{~cm}$, diameter $3 \mathrm{~cm}$ ) 160 was used to measure the relative soil density. Coordinates of each sample point were determined 161 with a portable global positioning system (GPS, Garmin ETrex 20).

162 Soil and organic matter samples were air-dried and passed through a $2 \mathrm{~mm}$ sieve before 163 analysis (Motsara \& Roy, 2008). The soil particle size distribution was determined by the 164 hydrometer method after a pre-treatment with sodium hexametaphosphate as a dispersant 165 (Bouyoucos, 1962) and classified according to the USDA soil texture triangle. The SOC was 166 measured with a total organic carbon analyzer TOC-VCSN (Shimadzu, Canby, USA). 


\section{Interpolation methods}

169 Different GIS-based deterministic and geostatistical interpolation techniques were used to map

170 the SOC and other environmental variables of the top soil layer (Scull et al., 2003). Deterministic

171 interpolation techniques create surfaces from measured sampling points based on either the

172 extent of similarity, the proximity and the spatial distribution of sampling points or the degree of

173 smoothing. Geostatistical interpolation techniques use a different approach and create surfaces

174 from the statistical properties of the measured sampling points. Three deterministic methods, i.e.

175 IDW, LPI and RBF, and three geostatistical interpolation techniques, i.e. OK, EBK and

176 cokriging (CK), were used to analyse the data and compared (Johnston et al., 2001).

177

178 Deterministic methods

179 The IDW is a determinist interpolation technique used most frequently to describe the spatial 180 distribution of SOC (Bhunia, Shit \& Maiti, 2018). The IDW method uses the sampling points

181 surrounding each prediction location to determine a SOC value for any unmeasured location. The 182 measured SOC values closest to the prediction location weight more on the predicted value than 183 those further away (Johnston et al., 2001). The best results with IDW are obtained when 184 sampling density is highly depended on the local variation (Watson \& Philip, 1985). The IDW is 185 described by the following equation.

186

$$
Z\left(x_{0}\right)=\frac{\sum_{i=1}^{N} \frac{x_{i}}{h_{i j}^{\beta}}}{\sum_{i=1}^{N} \frac{1}{h_{i j}^{\beta}}}
$$


188 where $Z\left(x_{0}\right)$ was the interpolated value, $N$ was the number of sample sites, $x_{i}$ was the $i$ th data

189 value, $h_{i j}$ represented the distance between interpolated value and the sample data value and

190 finally $\beta$ denoted the weighting power (ESRI, 2001; Liao et al., 2006).

191 The RBF method uses one of its five basis functions, i.e. thin-plate spline, spline with tension,

192 completely regularized spline, multiquadric function and inverse multiquadric function, to

193 interpolate surfaces that pass through the input sampling points exactly. Each basis function has

194 a different shape and results in different interpolation surfaces. The objective of each function is

195 to minimise the total curvature of the interpolation surface (Johnston et al., 2001). The RBFs

196 differ from the global and local polynomial interpolators, both inexact interpolators that do not

197 require the surface to pass through the measured sampling points. The RBFs are unsuitable when

198 the SOC of neighbouring sampling points is highly variable (ESRI, 2001; Losser, Li \& Piltner, 199 2014).

200 The LPI method does not make an exact interpolation, as the surface generated does not have 201 to pass through all measured sampling points of a predetermined square. The surface generated 202 from LPI is smooth and does not present cusps. For a correct use of LPI, the neighbourhood must 203 be itemised correctly. Similar values found in sampling points close to each other enable to 204 maximize the results as the method can produce surfaces that capture the short-range variation 205 (ESRI, 2001).

207 Geostatistical interpolation methods

208 The OK method assigns weights to neighbouring sampling points. Sampling points close to each 209 other have a strong effect on the results. The OK incorporates the statistical properties of the 210 sampling dataset through autocorrelation and the kriging weights come from a semivariogram 
211 developed in correlation with the spatial structure of the sampling dataset (ESRI, 2001). In OK

212 the values at the unsampled locations $Z^{*}\left(x_{0}\right)$ was determined by a linear weighted moving

213 average of the values at the sampled locations (Isaaks \& Srivastava, 1989), i.e.:

214

$$
Z^{*}\left(x_{0}\right)=\sum_{i=1}^{N} \lambda_{i} * Z\left(x_{i}\right)
$$

$$
\sum_{i=1}^{N} \lambda_{i}=1
$$

218 where $\lambda_{i}$ is the weight assigned to the known value of the variable at location $x_{i}$ determined based on a semivariogram model, and $N$ represent the number of neighbouring observations.

220 The error estimation variance $\sigma^{2}{ }_{k}\left(x_{0}\right)$ at any point $x_{0}$ was estimated as:

$$
\sigma_{k}^{2}\left(x_{0}\right)=\mu+\sum_{i=1}^{N} \lambda_{i} \gamma\left(x_{0}-x_{i}\right)
$$

where $\mu$ was the Lagrange parameter for minimisation the kriging variance and $\gamma\left(x_{0^{-}} x_{i}\right)$ was the semivariogram value corresponding to the distance between $x_{0}$ and $x_{i}$ (Vauclin et al., 1983; Agrawal et al., 1995).

226 The semivariogram was used as the basic tool to examine the spatial distribution structure of

227 the soil properties and was calculated using the following equation:

$$
\gamma(h)=\frac{1}{2 N(h)} \sum_{i=1}^{N(h)}\left[Z\left(x_{i}\right)-Z\left(x_{i}+h\right)\right]^{2}
$$


230 where $y(h)$ was the semivariance, $h$ the lag distance, $Z$ the parameter of the soil property, $N(h)$

231 was the number of pairs of locations separated by a lag distance $h, Z\left(x_{i}\right)$, and $Z\left(x_{i}+h\right)$ were

232 values of $Z$ at positions $x_{i}$ and $x_{i}+h$ (Wang \& Shao, 2013).

233 The EBK method requires minimal interactive modelling as it automates the steps to create a

234 kriging model and calculates the parameters through a process of sub setting and simulations.

235 The EBK technique generates many semivariogram models (spectrum of semivariograms) rather

236 than a single semivariogram. This differentiates it from other classical kriging methods and

237 makes it a robust non-stationary spatial prediction algorithm that can determine standard errors

238 of the predictions (Krivoruchko, 2012; Krivoruchko \& Butler, 2013).

239 Cokriging uses additional datasets or secondary variables (up to four) to refine the predicted

240 values of primary variable and, hypothetically, to create a map with greater precision. The

241 addition of the secondary variables to CK allows to reduce the variance of the estimation error.

242 These secondary variables are generally spatially cross correlated with the main variable (Yalçin,

243 2005). The normalized difference vegetation index (NDVI) altitude and terrain slope were the

244 secondary variables used in this study.

245

246 Cross-validation of the different methods

247 Cross-validation is a statistical method to determine the efficiency of algorithms of different

248 interpolation techniques by dividing the sampling points into two datasets. In this study, the data

249 set was divided into two groups at random each covering uniformly the study area. The first

250 group of data with 395 samples was used to construct the thematic SOC maps and the second

251 with 45 remaining samples to cross-validate the results. The following criteria were used to

252 select the second data group. The minimum distance between the samples was greater generally

Peer) reviewing PDF | (2019:05:37595:1:1:NEW 28 Aug 2019) 
253 than one $\mathrm{km}$ and the number of samples was proportional to the extension of the different

254 landscapes, i.e. 7 samples from the grassland, 17 from the forest and 21 from the agriculture

255 fields. The samples were taken as much as possible from the four cardinal points of the

256 mountain.

257 The indices used for cross-validation were: mean standardized error (ME), root mean square

258 error (RMSE) and mean relative error (MRE) (Yang et al., 2009; Bhunia, Shit \& Pourghasemi,

259 2019):

260

$M E=\frac{\sum_{i=1}^{N}\left[Z\left(x_{i}\right)-Z^{\prime}\left(x_{i}\right)\right]}{N}$

261

262

$$
R M S E=\sqrt{\frac{\sum_{i=1}^{N}\left[Z\left(x_{i}\right)-Z^{\prime}\left(x_{i}\right)\right]^{2}}{N}}
$$

$$
M R E=\frac{R M S E}{\Delta}
$$

with $Z\left(x_{i}\right)$ the measured value of SOC of each sampling point, $Z^{\prime}\left(x_{i}\right)$ the predicted value derived maximum and minimum data obtained.

\section{Calculation of carbon stocks}

271 The SOC stock $_{\mathrm{i}}$ for each point was determined as given by FAO (2018): 


$$
\text { SOC stock }_{i}=\frac{T * S O C_{i} * B_{i} *\left(1-C_{i} / 100\right)}{10}
$$

275

276

278

279

280

281

282

283

284

285

286

287

288

289

290

291

292

293

294

where SOC stock $_{\mathrm{i}}$ is expressed in $\mathrm{t} \mathrm{C} \mathrm{ha}^{-1}$, $\mathrm{T}$ is the $15 \mathrm{~cm}$ top soil layer for the A horizon or the thickness of the $\mathrm{O}$ horizon, $\mathrm{B}$ is the bulk density $\left(\mathrm{g} \mathrm{cm}^{-3}\right), \mathrm{SOC}$ is the soil organic carbon content $\left(\mathrm{g} \mathrm{kg}^{-1}\right)$ and $\mathrm{C}$ is the volume percentage of the $>2 \mathrm{~mm}$ fraction in the soil layer. The total SOC stock of the NPLM was calculated as:

Total SOC stock $=\left(\sum_{i=1}^{n} \overline{\text { SOC stock }_{i}} * S_{i}\right) * 10^{-6}$

where the total SOC stock is expressed in Tg. The SOC stock $\left(\mathrm{Mg} \mathrm{ha}^{-1}\right)$ is the mean soil organic carbon stock of each specific landscape (forest, agricultural land, grassland) and each horizon, $\mathrm{S}_{\mathrm{i}}$ (ha) the area of each landscape.

\section{The NDVI index}

The NDVI derived from the Landsat 8 imagery Operational Land Imager (OLI) is an indicator of vegetation growth, coverage and biomass, based on the "greenness" of a defined area (Tucker, 1979; Tucker et al., 2005). The data contained 12 monthly satellite imageries (January to December 2017) acquired from the USGS global visualization viewer (https://glovis.usgs.gov). The Landsat 8 imageries OLI were processed with the atmospheric correction algorithm "dark object subtraction" (DOS1) (Ding et al., 2015) and the reflectance data were used instead of digital numbers. The algorithm was developed in QGIS through the semi-automatic classification 
295 plugin (SCP) that allows a semi-automatic classification (also supervised and unsupervised 296 classification) of remote sensing images (Landsat, Sentinel-2, Sentinel-3, ASTER, MODIS)

297 (Congedo, 2016). Individual Landsat 8 TM bands include near-infrared (NIR) and red (RED).

298 The NDVI of each Landsat 8 imagery was determined using NIR and RED bands as reported by 299 Tucker \& Sellers (1986) (Equation 11).

$$
N D V I=(N I R-R E D) /(N I R+R E D)
$$

\section{RESULTS}

\section{Spatial variation of soil organic carbon content}

The summary statistics of the SOC in the A horizon are given in Table 1. Statistics of the SOC in the A horizon related to land use and altitude are given in Figure 2 and Table 2. cultivated crops were predominant in this area. The SOC in the A horizon ranged from $3.12 \mathrm{~g} \mathrm{~kg}^{-}$

311 from coarse sand to sandy loam. Generally, the arable soil did not have an O horizon, except for

312 some fields were conservation agricultural practices were applied, i.e. crop residue was retained

313 on the soil surface, where its thickness reached $3 \mathrm{~cm}$. In the latter, the SOC varied between

$314289.12 \mathrm{~g} \mathrm{~kg}^{-1}$ and $387.27 \mathrm{~g} \mathrm{~kg}^{-1}$.

315 Between 2,500 and 3,000 masl, the climate is temperate sub-humid. This area was

316 characterised by pine, oak forest and cultivated crops. The SOC in the A horizon varied between

$3172.33 \mathrm{~g} \mathrm{~kg}^{-1}$ and $44.32 \mathrm{~g} \mathrm{~kg}^{-1}$ with mean $13.24 \mathrm{~g} \mathrm{~kg}^{-1}$, standard deviation $11.64 \mathrm{~g} \mathrm{~kg}^{-1}$ and 
318 skewness 0.93 . The soil texture varied from coarse sand to sandy loam. In the forest soils, the $\mathrm{O}$

319 horizon reached $16 \mathrm{~cm}$ and the SOC varied between $287.82 \mathrm{~g} \mathrm{~kg}^{-1}$ and $412.47 \mathrm{~g} \mathrm{~kg}^{-1}$.

320 Between 3,000 and 3,500 masl, the climate is semi-cold and sub-humid. The vegetation was

321 composed mainly of pine and fir. The SOC in the A horizon was highly variable due to the

322 heterogeneous characteristics of the landscape and ranged from $2.81 \mathrm{~g} \mathrm{~kg}^{-1}$ and $100.82 \mathrm{~g} \mathrm{~kg}^{-1}$,

323 with mean $46.90 \mathrm{~g} \mathrm{~kg}^{-1}$, standard deviation $17.50 \mathrm{~g} \mathrm{~kg}^{-1}$ and skewness 0.28 . The soil texture was

324 mostly sandy loam. The thickest $\mathrm{O}$ horizons that were found in this area in some places

325 measured $35 \mathrm{~cm}$. The $\mathrm{SOC}$ in this area varied between $291.23 \mathrm{~g} \mathrm{~kg}^{-1}$ and $484.20 \mathrm{~g} \mathrm{~kg}^{-1}$.

326 Between 3,500 and 4,000 masl, the climate is cold. Pine forests were found throughout this

327 area with Pinus hartwegii Lindley 1839 in the highest zone. The SOC in the A horizon varied

328 between $8.12 \mathrm{~g} \mathrm{~kg}^{-1}$ and $114.87 \mathrm{~g} \mathrm{~kg}^{-1}$, with the highest amounts found in a pine forest at

329 approximately 3,750 masl. The mean SOC content was $38.42 \mathrm{~g} \mathrm{~kg}^{-1}$, standard deviation $25.85 \mathrm{~g}$

$330 \mathrm{~kg}^{-1}$ and skewness 0.98 . The predominant regosol soil had a sandy loam texture. The $\mathrm{O}$ horizon

331 varied between 2 and $30 \mathrm{~cm}$ and the SOC ranged from $284.76 \mathrm{~g} \mathrm{~kg}^{-1}$ to $473.12 \mathrm{~g} \mathrm{~kg}^{-1}$.

332 Over 4,000 masl, the vegetation was limited to grasses and high moor. The morphology on

333 the top of the volcano was relatively young with steep peaks and little soil (regosol) on the more

334 recent volcanic deposits. The regosol had a coarse sand or sandy loam texture. The SOC in the A

335 horizon varied between $2.63 \mathrm{~g} \mathrm{~kg}^{-1}$ and $21.73 \mathrm{~g} \mathrm{~kg}^{-1}$ with mean $12.82 \mathrm{~g} \mathrm{~kg}^{-1}$, standard deviation

$3365.28 \mathrm{~g} \mathrm{~kg}^{-1}$ and skewness 0.90 indicating a homogenous SOC spatial distribution. The $\mathrm{O}$ horizon

337 was $<2 \mathrm{~cm}$ due to accentuated slopes and water and wind erosion with a SOC of $315.39 \mathrm{~g} \mathrm{~kg}^{-1}$.

338 The peak of the mountain (70 ha approximately) was exclusively made up of volcanic stones 339 and no soil was formed yet. 


\section{The NDVI of forest landscape}

342 The NDVI varied between 0.23 and 0.46 (mean 0.32 ) in the forest of NPLM (Figure 3). The

343 highest NDVI was found in the state of Tlaxcala (Northern part of NPLM) and ranged from 0.35

344 to 0.40 . This area was also characterized by the highest SOC in the A horizon ranging from

$34567.32 \mathrm{~g} \mathrm{~kg}^{-1}$ to $100.81 \mathrm{~g} \mathrm{~kg}^{-1}$ (Figure 3A). In the state of Puebla (Southern part of NPLM), the

346 NDVI of the forest varied between 0.25 and 0.32 while the SOC in the A horizon ranged from

$34734.66 \mathrm{~g} \mathrm{~kg}^{-1}$ to $71.53 \mathrm{~g} \mathrm{~kg}^{-1}$. In the NPLM, the NDVI values were positively correlated with SOC

348 in the A horizon (Figure 3B) and SOC in the O horizon.

\section{SOC stocks variability and total SOC stock}

351 The SOC stocks in the A horizon in the NPLM ranged from 3.81 to $196.33 \mathrm{t} \mathrm{C} \mathrm{ha}^{-1}$ (Table 3).

352 These SOC stocks were significantly higher in the forest than in the high moor and arable soils.

353 The mean SOC stock in the forest was $68.94 \mathrm{t} \mathrm{C} \mathrm{ha}^{-1}$ and only $8.82 \mathrm{t} \mathrm{C} \mathrm{ha}^{-1}$ in the arable soil. The 354 arable soils in the state of Tlaxcala with limited tillage had a higher SOC stock (mean $20.51 \mathrm{t} \mathrm{C}$ $355 \mathrm{ha}^{-1}$ ) than those in the state of Puebla (mean $4.14 \mathrm{t} \mathrm{C} \mathrm{ha}^{-1}$ ) where more conventional agricultural 356 practices prevailed. The mean SOC stocks was $21.81 \mathrm{t} \mathrm{C} \mathrm{ha}^{-1}$ in the grassland and moor soil.

357 The SOC stocks in the O horizon in the NPLM ranged from $0 \mathrm{t} \mathrm{C} \mathrm{ha}^{-1}$ to $386.23 \mathrm{t} \mathrm{C} \mathrm{ha}^{-1}$. The 358 O horizon was highly variable with mean $5.31 \mathrm{~cm}$ in the forest soils, much lower in the high359 altitude grassland with mean value less than $2 \mathrm{~cm}$ and almost non-existent in the arable soil.

360 The total SOC stock of NPLM was 2.44 Tg C. The forest had a SOC stock of 2.09 Tg C

361 (85.31\% of the total) with $1.26 \mathrm{Tg} \mathrm{C}$ in the $\mathrm{A}$ horizon and $0.83 \mathrm{Tg} \mathrm{C}$ in the $\mathrm{O}$ horizon. The total 362 SOC in the arable soil was $0.28 \mathrm{Tg} \mathrm{C}(11.40 \%)$ with $0.23 \mathrm{Tg}$ in the A horizon and only $0.05 \mathrm{Tg}$ 
$363 \mathrm{C}$ in the $\mathrm{O}$ horizon. The contribution of the high moor areas to the SOC stock was small and only

$3640.07 \mathrm{Tg} \mathrm{C}$ or $3.31 \%$ of the total SOC in NPLM.

365 The estimated total SOC stock in a preserved part of the forest in NPLM was $4.98 \mathrm{Tg} \mathrm{C}$ in

3661938 and has nearly halved since then. If this trend continues and all the remaining forest is

367 converted to arable land, then the total SOC stock would drop to $0.52 \mathrm{Tg} \mathrm{C}$.

\section{Interpolation methods results}

370

371

372

373

374

375

376

377

378

379

All interpolation methods described the spatial distribution of SOC stocks in the NPLM satisfactorily (Figures 4-5). The summary statistics of the six interpolation methods showed that the CK method was more accurate than the other interpolation methods with a coefficient of efficiency ( $\mathrm{R}^{2}$ values) of 0.87 . The deterministic LPI method gave the lowest $\mathrm{R}^{2}$ of 0.82 (Table 4).

The RMSE varied from 14.157 of the IDW model to 15.288 of the LPI model. The variation in ME was low and varied from -4.282 of the OK model to -6.283 of the LPI model. The LPI technique resulted in the lowest MRE (0.095) while the CK the highest (0.103). The cross validation analysis showed that IDW, RBF, CK, OK and EBK models were better than the LPI model to predict SOC stock distribution in the NPLM.

$$
\text { The semivariogram analysis with OK indicated that the SOC stock data (log transformed) }
$$
were best fitted with an exponential model with nugget 0.529 , sill 2.226 and a nugget - sill ratio of 0.23 . No significant differences were found in cross validation indices and $\mathrm{R}^{2}$ between the $\mathrm{OK}$ and CK methods. Consequently, the spatial autocorrelation, density and number of samples (distance between sampling points) were sufficient for a high quality and precision SOC map. In 
385 this ecosystem, other parameters, such as NDVI, altitude and terrain slope, played a secondary 386 role in the SOC stocks spatial distribution.

387

388

389

390

391

392

394

395

396

398

399

400

401

402

403

404

405

406

407

\section{DISCUSSION}

\section{The effect of land use on SOC and SOC stocks}

The SOC accumulation depends largely on vegetation and the quantity and quality of organic material input (Signor et al., 2016). The SOC drops quickly when land use changes but even more so when natural ecosystems are converted to arable land (Guo \& Gifford, 2002; Wilson, Growns, \& Lemon, 2008).

In this study, the SOC stocks in the arable soil were low compared to other values reported for arable soils (Wang et al., 2004; Pan, Zhang \& Zhao, 2005; Liu, Shao \& Wang, 2011; Zhao et al., 2017). For instance, Campos, Aguilar \& Landgrave (2014) reported a mean SOC stock of 151.10 $\mathrm{t} \mathrm{C} \mathrm{ha-1} \mathrm{for} \mathrm{the} \mathrm{top} 1 \mathrm{~m}$ layer of an arable soil from Veracruz (Gulf of Mexico, Mexico) with 36\% of the $\mathrm{C}$ stock in the first $20 \mathrm{~cm}$. The conventional agricultural practices in NPLM consist of maize monoculture, tillage, and removal of crop residue for fodder or fuel, or burning it (Arriaga-Cabrera et al., 2009). These practices reduced strongly the soil organic matter content (Bellamy et al., 2005; Du, Ren \& Hu, 2010; Moussadek et al., 2014). Additionally, heavy intense rainfall favours water erosion on the steep slopes, while the bare soil promotes wind erosion during the dry season eliminating the top soil layer with its higher organic matter content.

Conservation agricultural practices with reduced tillage, crop rotation and retention of the crop residues in the field have been shown to reduce soil erosion, while increasing the SOC (West \& Post, 2002; Dabney et al., 2004). These conservation agriculture practices are not widespread in NPLM although more common in the state of Tlaxcala than in the state of Puebla and 
408 conventional practices, i.e. tillage, crop residue removal and maize monoculture, prevail. The 409 more traditional milpa system, i.e. a legume based rotation system, which would increase soil 410 organic matter content has been largely abandoned in this area as it is labour intensive. Some 411 farmers apply farmyard manure to some of their fields although the lack of farm animals limits 412 this practice (Wang et al., 2004). All these different agricultural management practices explain 413 why the soil organic matter content is so variable in the arable soils of NPLM (Gregorich, Drury 414 \& Baldock, 2001).

415 The SOC stocks of the forest soils were highly variable, but the mean of $68.90 \mathrm{t} \mathrm{C} \mathrm{ha}^{-1}$ was 416 similar to those reported by Domke et al. (2017) for forests in the USA and for high mountain 417 ecosystems of the Peruvian Andes (Zimmermann et al., 2010). Liu, Shao \& Wang (2011) 418 reported SOC stocks between 72.00 and $145.00 \mathrm{t} \mathrm{C} \mathrm{ha}^{-1}$ for forested areas in the loess plateau 419 region of China. Different factors explain the large variations in SOC stocks found in this study. 420 First, the forest vegetation varied with altitude, i.e. mixed forest of oak and pine on the lower 421 slopes and pine on the higher slopes. The type and density of vegetation are known to affect the 422 SOC and SOC stocks (Guo \& Gifford, 2002) and is regarded as one of its principal determinants 423 (Vargas, Allen \& Allen, 2008; Chuai et al., 2014; Mondal et al., 2017). The SOC in a mixed 424 pine-oak forest soil is higher generally than in a pine forest and converting a natural forest to a 425 coniferous plantation or selectively logging the oak trees is found to reduce the SOC stock (Guo $426 \&$ Gifford, 2002). Second, logging for wood to produce charcoal or for Christmas trees is absent 427 in some parts of the forest, but more intensive in others, e.g. the state of Puebla (Arriaga428 Cabrera et al., 2009). Logging reduces the vegetation so that fewer leaves replenish the soil 429 organic matter (Garcia-Pausas et al., 2007; Dorji, Odeh \& Field, 2014; Zhang et al., 2015; 430 Mondal et al., 2017). Additionally, logging trees reduces soil cover, making the soil more prone 
431 to water and wind erosion (Zhou et al., 2008). Contrastingly, a reduction of the tree canopy

432 stimulates the growth of shrubs and smaller plants that might reduce erosion and increase the soil 433 organic matter content (van Kuijk et al., 2014). Third, burning the unwanted vegetation on the 434 arable land spreads often to the surrounding forests reducing strongly the organic layer there. 435 Fourth, mixed forest (principally pine and oak) and coniferous forests are found at between 2,000 436 and 3,400 masl in Mexico (Carabias et al., 2010). Altitude is known to affect vegetation that 437 ultimately will affect the soil organic matter content (Körner, 2003; Djukic et al., 2010). Several studies have shown that SOC stocks increased generally up to a certain altitude and decreases at even higher altitudes as plant growth decreases (Segnini et al., 2011; Oueslati et al., 2013). Fifth, soils of NPLM are mostly sandy loam. Organic material is less physically protected in sandy

441 loam soils than in clayey soil so mineralization is higher in the first than in the latter.

442 Consequently, the SOC is larger generally in clay soils than in sandy loam soils (Lefèvre et al., 443 2017). Sixth, the orientation of the slopes in the NPLM determines sunshine, temperature, 444 rainfall and indirectly the structure of the forests, which will ultimately affect the SOC stock and 445 distribution.

446 The top of the mountain was covered exclusively with grasses and the SOC stocks were 447 similar to those reported by Kopáček, Kaňa \& Šantrůčková (2006) for alpine meadows of the 448 Tatra Mountains, but lower than those reported in other studies (Garcia-Pausas et al., 2007; 449 Montané, Rovira \& Casals, 2007; Djukic et al., 2010). Differences in SOC stocks between 450 grasslands ecosystems are due to environmental, climatic, geological origin and geographical 451 conditions. The shallow soil on the mountain top, the steep slopes, the wind and water erosion, 452 and the harsh climate strongly reduced vegetation growth and the SOC stocks in the grassland 453 soil of NPLM. 
454 The SOC in the A horizon decreased in the order: forest soil $>$ natural grassland soil $>$ arable 455 soil at NPLM, as reported in other studies. Gurumurthy, Kumar \& Prakasha (2009) and Saha, 456 Chaudhary \& Somasundaram (2012) reported that SOC and SOC stocks were significantly 457 higher in the top layer of forest soil than in the adjacent arable land and natural grassland. 458 Kocyigit \& Demirci (2012) reported a mean SOC content of $44.70 \mathrm{~g} \mathrm{C} \mathrm{kg}^{-1}$ in the top $0-15 \mathrm{~cm}$ 459 forest soil layer, $25.10 \mathrm{~g} \mathrm{C} \mathrm{kg}^{-1}$ in grassland and $14.70 \mathrm{~g} \mathrm{C} \mathrm{kg}^{-1}$ in the arable soil, similar to those 460 of NPLM. Generally, the loss of organic material and litter from cultivated or perturbed forest

461 462 463 464 465 466 467 soils is higher than the amount that enters in undisturbed soils. Consequently, the amount of SOC retained in cultivated or perturbed forest soils reduces and this explains the differences in SOCs in the different landscapes of the NPLM (Reicosky, 2002). These results can be compared with values reported by Stumpf et al. (2018). They reported SOC of $30 \mathrm{~g} \mathrm{C} \mathrm{kg}^{-1}$ for areas dominated by grassland and $17 \mathrm{~g} \mathrm{C} \mathrm{kg}^{-1}$ for agricultural soils in Switzerland. Campos, Aguilar \& Landgrave (2014) reported that the SOC was higher in a forest soil than in a natural grassland and arable soil in the state of Veracruz (Mexico).

Approximately 50\% of the forest $\mathrm{C}$ stocks are found in the soil (Pan et al., 2011; Valtera \& Šamonil, 2018) and the remaining part in the living and dead forest biomass. As such, the effect of deforestation on the $\mathrm{C}$ stocks in the forest vegetation is of the same magnitude as that on the $\mathrm{C}$ stocks in the forest soil.

Griffithsa, Madritchab \& Swanson et al. (2009) stated that SOC stocks in mountain ecosystems are controlled by temperature and soil moisture at different elevations. Altitude had an effect on vegetation, soil type and consequently SOC stock (Bangrooa, Najara \& Rasool, 2017). In this study, the maximum SOC stock was found in the pine forest at approximately 
4763,750 masl. Above 4,000 $\mathrm{m}$, the decline in total tree density, reduction in the basal area and

477 species richness decreased significantly the SOC stocks as reported Korner (1998).

478

479 Comparison of interpolation methods

480 Each of the GIS based interpolation methods used in this study described the spatial distribution 481 of SOC in the O and A horizon in the NPLM satisfactorily. Consequently, the density and 482 geographical distribution of the samples were sufficient for thematic maps of high quality.

483 The geostatistic OK technique was the best of the five mono parametric methods. It included 484 spatial autocorrelation, which optimized statistically the weights of all sample sites. Zhang et al. 485 (2011), Mousavifard et al. (2012) and Bhunia, Shit \& Maiti (2018) stated that the OK method

486

487

488

489

490

491

492

493

494

495

496

497

498 was better to map soil patterns than other GIS based methods. In this study, the semivariogram analysis indicated that SOC was best fitted with an exponential model as the nugget - sill ratio was 0.23 and $<25 \%$, which indicated strong spatial dependency (Cambardella et al., 1994).

Although the results of the $\mathrm{CK}$ and $\mathrm{OK}$ techniques were comparable, the CK method was better as additional secondary variables were used. Zare-mehrjardi et al. (2010) reported that the $\mathrm{OK}$ and $\mathrm{CK}$ methods were better than other determination interpolation techniques, such as IDW, to predict spatial distribution of soil characteristics. In this study, the OK and CK methods gave better results than the EBK method.

In this study, the deterministic methods were less good than the geostatistic interpolation techniques as reported by Bhunia, Shit \& Maiti (2018). Of the three deterministic methods used in this study, the best results were obtained with the IDW method as reported by Tang et al. (2017). Sarmadian et al. (2014) stated that the RBF interpolation method gave satisfactory results for a SOC map, but not in this study.

Peer) reviewing PDF | (2019:05:37595:1:1:NEW 28 Aug 2019) 
500 Hypothetical scenarios

501 The area around the Malinche volcano was declared a protected national park by Presidential

502 Decree in 1938 (Official Gazette on October 6, 1938). The majority of the mountain was covered

503 with forest except for the higher altitudes. The lack of roads did not allow intensive culling of

504 trees and the extraction of wood was limited. Since then, roads have been built, and although

505 most remain unpaved, some connections have been asphalted. This facilitated access to the forest

506 and increased culling of the trees. It aided also to convert more forest to arable land, which

507 nowadays covers $50 \%$ of the NPLM (SEMARNAT, 2013). The forest in Tlaxcala retains most of

508 its primary vegetation (pines and oaks) and the shrubby vegetation of the flowering underbrush is

509 dense, as was confirmed by NDVI values of 0.40 . This area was also characterized by the highest

510 SOC contents (67.32 to $\left.100.81 \mathrm{~g} \mathrm{~kg}^{-1}\right)$. It can be assumed based on these values that the total

511 SOC stock in the NPLM was approximately $4.98 \mathrm{Tg} \mathrm{C}$ in 1938 , but it is only $2.45 \mathrm{Tg} \mathrm{C}$ now. If

512 this trend goes on unabated and all forest is converted to arable land then the SOC stock would

513 drop to only $0.52 \mathrm{Tg} \mathrm{C}$.

514 Recently, national authorities have promoted a program for the sustainable exploitation of the

515 NPLM to safeguard it (SEMARNAT, 2013). The aim of this program is to restore as much as

516 possible of the ecosystem as it was prior to 1938, i.e. to stop the conversion of forest to arable

517 land, illegal logging and forest fires. As such, the program aims to stop the decline in SOC stock

518 and ideally increase it.

519 Temperate forests in Mexico are the second largest biome in the country (21\% of national

520 territory) (https://www.biodiversidad.gob.mx; Guzmán-Mendoza et al., 2014). Most of these

521 forests (pine and oak forests) are found on the mountains of the Trans-Mexican Volcanic Belt. 
522 Apart from the NPLM, other national parks, and protected areas for flora and fauna can be found

523 on the Trans-Mexican Volcanic Belt, i.e. Iztaccíhuatl - Popocatépetl park covering $398 \mathrm{~km}^{2}$, Pico

524 de Orizaba $197 \mathrm{~km}^{2}$, Cofre de Perote $117 \mathrm{~km}^{2}$, and Nevado de Toluca $467 \mathrm{~km}^{2}$

525 (http://sig.conanp.gob.mx). Deforestation and land use change are the main reasons for the

526 degradation of these ecosystems. They are the result of technological, economic, political, social

527 and cultural factors and/or a combination of them (Fuentes \& Ramírez, 2016). As such, any

528 program that tries to create sustainable forest ecosystems should try to address these factors also.

529 Considering the large areas these forests cover, large amounts of $\mathrm{C}$ could be sequestered if the

530 promoted sustainable programs are successful.

531 The results of this study can be used for reforestation strategies of the most deteriorated areas

532 of NPLM so as to increase ultimately the total SOC stock under the program "Sembrando Vida"

533 of Mexican government (https://www.gob.mx). The program has the objective to contribute to

534 the social well-being of people in rural areas, increase their effective participation in integrated

535 rural development projects and increase the SOC stocks to mitigate global change. Although

536 cross-validation confirmed the high efficiency of the SOC spatial distribution maps in NPLM,

537 the next step will be to develop an algorithm based on Landsat 8 imagery OLI and remote

538 perception indices to further improve the map details.

539

540 CONCLUSION

541 The SOC content is controlled by different factors, but deforestation and agriculture are the ones

542 that affect it most. The decrease in SOC stocks is driven mostly by cultivating land that was

543 previously forest or grassland. The total SOC stock in the NPLM was approximately $4.98 \mathrm{Tg} \mathrm{C}$

544 in 1938 , but it is only $2.45 \mathrm{Tg} \mathrm{C}$ now, mainly due to the land use change and clandestine logging. 
545 The SOC and NDVI (indicator of biomass) were positively correlated, so a decrease in the

546 biomass $\mathrm{C}$ stocks might be of the same magnitude as in the soil. If this trend goes on unabated

547 and all forest is converted to arable land then the total SOC stock would drop to only $0.52 \mathrm{Tg} \mathrm{C}$.

548 Accurate mapping of land-use in the NPLM, limiting agriculture and sustainable logging could

549 help regional and state authorities to take measures to promote ecological conservation and

550 restoration of this area, thereby increasing SOC stocks substantially.

551

552 ACKNOWLEDGEMENTS

553 This research was funded by the project 'Infraestructura 253217', 'Ciencia Básica 256096' and

554 'Cátedras CONACyT 883” from 'Consejo Nacional de Ciencia y Tecnología' (CONACyT,

555 Mexico). Authors thank 'Centro de Investigación y de Estudios Avanzados del IPN'

556 (CINVESTAV-IPN, Mexico) for providing laboratory facilities and La Malinche Scientific

557 Station for logistical support. Carmine Fusaro and Ligia C. Muñoz - Arenas received grant-aided 558 support from CONACyT.

559

560 APPENDIX A. SUPPLEMENTARY MATERIAL

561 The raw measurements are provided in the supplementary file 1.

562

563

REFERENCES

564 Achat DL, Deleuze C, Landmann G, Pousse N, Ranger J, Augusto L. 2015.

565 Quantifying consequences of removing harvesting residues on forest soils and tree growth-A

566 meta-analysis. Forest Ecology and Management 348: 124-141 DOI

$567 \quad 10.1016 /$ j.foreco.2015.03.042. 
568 Agrawal OP, Rao KVGK, Chauhan HS, Khandelwal, MK. 1995. Geostatistical analysis of

569 soil salinity improvement with subsurface drainage system. Transactions of the ASAE 38:

570 1427-1433 DOI 10.13031/2013.27967.

\section{1}

572

573

574

575

576

577

578

579

580

581

582

583

584

585

586

587

588

589

590

Arriaga-Cabrera L, Aguilar V, Espinoza JM, Galindo C, Herrmann H, Santana E, GrafMontero S, Pisanty I, Rosenzweig L. 2009. Regiones prioritarias y planeación para la conservación de la biodiversidad. Capital Natural de México 2: 433-457.

Bellamy PH, Loveland PJ, Bradley RI, Lark RM, Kirk GJD. 2005. Carbon losses from all soils across England and Wales 1978-2003. Nature 437: 245-248 DOI 10.3410/f.1028579.343447.

Bhunia GS, Shit PK, Pourghasemi HR. 2019. Soil organic carbon mapping using remote sensing techniques and multivariate regression model. Geocarto International 34(2): 215-226 DOI 10.1080/10106049.2017.1381179.

Bhunia GS, Shit PK, Maiti R. 2018. Comparison of GIS-based interpolation methods for spatial distribution of soil organic carbon (SOC). Journal of the Saudi Society of Agricultural Sciences 17: 114-116 DOI 10.1016/j.jssas.2016.02.001.

Bouyoucos GJ. 1962. Hydrometer method for making particle size analysis of soil. Agronomy Journal 54: 464-465 DOI 10.2134/agronj1962.00021962005400050028x.

Bangroo SA, Najar, GR, Rasool A. 2017. Effect of altitude and aspect on soil organic carbon and nitrogen stocks in the Himalayan Mawer Forest Range. CATENA 158: 63-68 DOI 10.1016/j.catena.2017.06.017.

\section{Cambardella CA, Moorman TB, Novak JM, Parkin, TB, Karlen DL, Turco RF, Konopka} AE. 1994. Field-scale variability of soil properties in central Iowa soils. Soil Science Society of America Journal 58: 1501-1511 DOI 10.2136/sssaj1994.03615995005800050033x. 
591 Campos A, Aguilar G, Landgrave R. 2014. Soil organic carbon stocks in Veracruz State 592 (Mexico) estimated using the 1:250,000 soil database of INEGI: biophysical contributions. Journal of Soils and Sediments 14: 860-871 DOI 10.1007/s11368-014-0851-2.

594 Carabias J, Sarukhán J, de la Maza J, Galindo C. 2010. Patrimonio natural de México. Cien 595 casos de éxito. Comisión Nacional para el Conocimiento y Uso de la Biodiversidad, México.

596 Catalán N, Ortega SH, Gröntoft H, Hilmarsson TG, Bertilsson S, Wu P, Levanoni O, 597 Bishop K, Bravo AG. 2017. Effects of beaver impoundments on dissolved organic matter 598 quality and biodegradability in boreal riverine systems. Hydrobiologia 793: 135-148 DOI $599 \quad 10.1007 / \mathrm{s} 10750-016-2766-\mathrm{y}$.

600 Chabala LM, Mulolwa A, Lungu O. 2017. Application of ordinary kriging in mapping soil 601 organic carbon in Zambia. Pedosphere 27: 338-343

602 DOI 10.1016/S1002-0160(17)60321-7.

603 Chang KT. 2015. Introduction to geographic information systems, seventh ed. McGraw-Hill 604 Education.

605 Chen C, Hu K, Li H, Yun A, Li B. 2015. Three-dimensional mapping of soil organic carbon by 606 combining kriging method with profile depth function. PloS One 10: e0129038 DOI $607 \quad$ 10.1371/journal.pone.0129038.

608 Chuai X, Huang X, Wang W, Wu C, Zhao R. 2014. Spatial simulation of land use based on 609 terrestrial ecosystem carbon storage in coastal Jiangsu, China. Scientific Reports 4: 5667 DOI $610 \quad 10.1038 / \operatorname{srep} 05667$.

611 Clay DE, Shanahan JF. 2011. GIS Applications in Agriculture, Volume Two: Nutrient 612 Management for Energy Efficiency, first ed. CRC Press. 
613 Comisión Nacional de Áreas Naturales Protegidas (CONANP). http://sig.conanp.gob.mx $614 \quad$ (accessed 11 February 2018).

615 Congedo L. 2016. Semi-Automatic Classification Plugin Documentation. DOI $616 \quad 10.13140 /$ RG.2.2.29474.02242/1.

617 Dabney SM, Wilson GV, McGregor KC, Foster G.R. 2004. History, residue, and tillage 618 effects on erosion of loessial soil. Transactions of the ASAE 47: 767-775 DOI $619 \quad 10.13031 / 2013.16108$.

620

621

622

623

624

625

626

627

628

629

630

631

632

633

634

635

Ding M, Lanhui L, Zhang Y, Sun X, Liu L, Gao J, Wang Z, Li Y. 2015. Start of vegetation growing season on the Tibetan Plateau inferred from multiple methods based on GIMMS and SPOT NDVI data. Journal of Geographical Sciences 25: 131-148 DOI 10.1007/s11442-015$1158-y$

Djukic I, Zehetner F, Tatzber M, Gerzabek MH. 2010. Soil organic matter stocks and characteristics along an Alpine elevation gradient. Journal of Plant Nutrition and Soil Science 173: 30-38 DOI 10.1002/jpln.200900027.

Dodo MK. 2014. Examining the potential impacts of climate change on international security: EU-Africa partnership on climate change. SpringerPlus 3: 194 DOI 10.1186/2193-1801-3194.

Domke GM, Perry CH, Walters BF, Nave LE, Woodall CW, Swanston CW. 2017. Toward inventory-based estimates of soil organic carbon in forests of the United States. Ecological Applications 27: 1223-1235 DOI 10.1002/eap.1516.

Dorji T, Odeh IO, Field DJ. 2014. Vertical distribution of soil organic carbon density in relation to land use/cover, altitude and slope aspect in the eastern Himalayas. Land 3: 12321250 DOI 10.3390/land3041232. 
636 Du Z, Ren T, Hu C. 2010. Tillage and residue removal effects on soil carbon and nitrogen 637 storage in the North China Plain. Soil Science Society of America Journal 74: 196-202 DOI

638 10.2136/sssaj2009.0048.

639

640

641

642

643

644

645

646

647

648

649

650

651

652

653

654

655

656

657

658

ESRI Inc. 2001. Using analytic tools when generating surfaces. In: Geostatistical Analyst Extension. Redlands, CA:ESRI Inc.

FAO. 2008. Climate change and food security: a framework document. http://www.fao.org/docrep/pdf/010/k2595e/k2595e00.pdf (accessed 19 February 2018).

FAO. 2018. Measuring and modelling soil carbon stocks and stock changes in livestock production systems - Guidelines for assessment (Draft for public review). Livestock Environmental Assessment and Performance (LEAP) Partnership. FAO, Rome, Italy.

Feulner G. 2017. Global Challenges: Climate Change. Global Challenges 1: 5-6

DOI $10.1002 / \mathrm{gch} 2.1003$.

Fuentes JCC, Ramírez AV. 2016. Estudio legal: Facultades y responsabilidades del manejo forestal y del suelo ante REDD+ en México (Vol. 150). CIFOR

DOI 10.17528/cifor/006024.

Garcia-Pausas J, Casals P, Camarero L, Huguet C, Sebastia MT, Thompson R, Romanya J. 2007. Soil organic carbon storage in mountain grasslands of the Pyrenees: effects of climate and topography. Biogeochemistry 82: 279-289

DOI 10.1007/s10533-007-9071-9.

Gerber PJ, Steinfeld H, Henderson B, Mottet A, Opio C, Dijkman J, Falcucci A, Tempio G. 2013. Tackling climate change through livestock - A global assessment of emissions and mitigation opportunities. Food and Agriculture Organization of the United Nations (FAO), Rome. http://www.fao.org/3/a-i3437e.pdf (accessed 03 March 2018). 
659 Gobiet A, Kotlarski S, Beniston M, Heinrich G, Rajczak J, Stoffel M. 2014. 21 st century

660 climate change in the European Alps-a review. Science of the Total Environment 493: 1138-

$661 \quad 1151$ DOI 10.1016/j.scitotenv.2013.07.050.

662 Gobierno de México

663 https://www.gob.mx/bienestar/acciones-y-programas/programa-sembrando-vida (accessed 29 July

664 2019).

665 Gregorich EG, Drury CF, Baldock JA. 2001. Changes in soil carbon under long-term maize in

666 monoculture and legume-based rotation. Canadian Journal of Soil Science 81: 21-31 DOI

$667 \quad 10.4141 / \mathrm{S} 00-041$.

668 Griffiths RP, Madritch MD, Swanson AK. 2009. The effects of topography on forest soil

669 characteristics in the Oregon Cascade mountains (USA): implications for the effects of

670 climate change on soil properties. Forest Ecology and Management 257: 1-7 DOI

$671 \quad 10.1016 /$ j.foreco.2008.08.010

672 Guo LB, Gifford RM. 2002. Soil carbon stocks and land use change: a meta analysis. Global

673 Change Biology 8: 345-360 DOI 10.1046/j.1354-1013.2002.00486.x.

674 Gurumurthy KT, Kumar MK, Prakasha HC. 2009. Changes in physico chemical properties

675 of soils under different land use systems. Karnataka Journal of Agricultural Sciences 22:

$676 \quad 1107-1109$.

677 Guzmán-Mendoza R, Zavala-Hurtado JA, Castaño-Meneses G, León-Cortés JL. 2014.

678 Comparación de la mirmecofauna en un gradiente de reforestación en bosques templados del 679 centro occidente de México. Madera y Bosques 20(1): 71-83.

680 Houghton RA, Nassikas AA. 2018. Negative emissions from stopping deforestation and forest

681 degradation, globally. Global Change Biology 24: 350-359 
682

683

684

685

686

687

688

689

690

691

692

693

694

695

696

697

698

699

700

701

702

DOI $10.1111 / \mathrm{gcb} .13876$.

Instituto Nacional de Estadística y Geografía (INEGI).

http://www.inegi.org.mx/geo/contenidos/datosrelieve/continental/continuoelevaciones.aspx. (accessed 25 January 2018).

Isaaks EH, Srivastava RM. 1989. An introduction to applied geostatistics, first ed. Oxford University Press.

IUSS Working Group. 2015. World Reference Base for Soil Resources 2014, update 2015 International soil classification system for naming soils and creating legends for soil maps. World Soil Resources Reports, (106). http://www.fao.org/3/i3794en/I3794en.pdf.

Jandl R, Lindner M, Vesterdal L, Bauwens B, Baritz R, Hagedorn F, Johnson DW, Minkkinen K, Byrne KA. 2007. How strongly can forest management influence soil carbon sequestration? Geoderma 137: 253-268 DOI 10.1016/j.geoderma.2006.09.003.

Jeelani J, Kirmani NA, Sofi JA, Mir SA, Wani JA, Rasool R, Sadat S. 2017. An overview of spatial variability of soil microbiological properties using geostatistics. International Journal of Current Microbiology and Applied Sciences 6: 1132-1145 DOI

$$
\text { 10.20546/ijcmas.2017.604.140. }
$$

Johnston K, Ver Hoef JM, Krivoruchko K, Lucas N. 2001. Using ArcGIS geostatistical analyst. Esri, Redlands, CA, USA.

Karydas CG, Gitas IZ, Koutsogiannaki E, Lydakis-Simantiris N, Silleos GN. 2009. Evaluation of spatial interpolation techniques for mapping agricultural topsoil properties in Crete. EARSeL eProceedings 8: 26-39. 
703 Kocyigit R, Demirci S. 2012. Long-term changes of aggregate-associated and labile soil organic

704 carbon and nitrogen after conversion from forest to grassland and cropland in northern

705 Turkey. Land Degradation \& Development 23: 475-482 DOI 10.1002/ldr.1092.

706 Kopáček J, Kaňa J, Šantrůčková H. 2006. Pools and composition of soils in the alpine zone of 707 the Tatra Mountains. Biologia 61: S35-S49 DOI 10.2478/s11756-006-0118-5.

708 Korner C. 1998. A re-assessment of high elevation of tree line positions and their explanations. 709 Oecologia 115: 445-459 DOI 10.1007/s004420050540.

710 Körner C. 2003. Alpine plant life. Functional plant ecology of high mountain ecosystems, 711 second ed. Springer.

712 Krivoruchko K. 2012. Empirical Bayesian Kriging. Esri, Redlands, CA, USA.

713 http://www.esri.com/news/arcuser/1012/files/ebk.pdf.

714 Krivoruchko K, Butler K. 2013. Unequal Probability-Based Spatial Mapping. Esri, Redlands, 715 CA, USA. http://www.esri.com/esri-news/arcuser/spring-2013/unequal-probability-based716 spatial-sampling.

717 Lal R. 2004. Soil carbon sequestration impacts on global climate change and food security.

$718 \quad$ Science 304: 1623-1627 DOI 10.1126/science.1097396.

719 Lal R. 2008. Carbon sequestration Philosophical Transactions of the Royal Society of London B:

$720 \quad$ Biological Sciences 363: 815-830 DOI 10.1098/rstb.2007.2185.

721 Lefèvre C, Rekik F, Alcantara V, Wiese L. 2017. Soil organic carbon: the hidden potential. 722 Food and Agriculture Organization of the United Nations (FAO).

723 Liao D, Peuquet DJ, Duan Y, Whitsel EA, Dou J, Smith RL, Lin HM, Chen JC, Heiss G. 2006. GIS approaches for the estimation of residential-level ambient PM concentrations. 725 Environmental Health Perspectives 114: 1374-1380 DOI 10.1289/ehp.9169. 
726 Liu L, Wang H, Dai W, Lei X, Yang X, Li X. 2014. Spatial variability of soil organic carbon in

727 the forestlands of northeast China. Journal of Forestry Research 25: 867-876 DOI

$728 \quad 10.1007 / \mathrm{s} 11676-014-0533-3$.

729 Liu Z, Shao MA, Wang Y. 2011. Effect of environmental factors on regional soil organic

730 carbon stocks across the Loess Plateau region, China. Agriculture, Ecosystems \&

731 Environment 142: 184-194 DOI 10.1016/j.agee.2011.05.002.

732 Losser T, Li L, Piltner R. 2014. A spatiotemporal interpolation method using radial basis

733 functions for geospatiotemporal big data. In Computing for Geospatial Research and

734 Application (COM. Geo), 2014 Fifth International Conference on (pp. 17-24). IEEE. DOI

$735 \quad$ 10.1109/COM.Geo.2014.15.

736 Mondal A, Khare D, Kundu S, Mondal S, Mukherjee S, Mukhopadhyay A. 2017. Spatial

737 soil organic carbon (SOC) prediction by regression kriging using remote sensing data. The

738 Egyptian Journal of Remote Sensing and Space Science 20: 61-70

739 DOI 10.1016/j.ejrs.2016.06.004.

740 Montané F, Rovira P, Casals P. 2007. Shrub encroachment into mesic mountain grasslands in

741 the Iberian peninsula: effects of plant quality and temperature on soil C and N stocks. Global

742 Biogeochemical Cycles 21 DOI 10.1029/2006GB002853.

743 Motsara MR, Roy RN. 2008. Guide to laboratory establishment for plant nutrient analysis (Vol.

744 19). Rome: Food and Agriculture Organization of the United Nations.

745 Mousavifard SM, Momtaz H, Sepehr E, Davatgar N, Sadaghiani MHR. 2012. Determining

746 and mapping some soil physico-chemical properties using geostatistical and GIS

747 techniques in the Naqade region, Iran. Archives of Agronomy and Soil Science 59: 1573-

$748 \quad 1589$ DOI $10.1080 / 03650340.2012 .74055$. 
749 Moussadek R, Mrabet R, Dahan R, Zouahri A, El Mourid M, Ranst EV. 2014. Tillage

750 system affects soil organic carbon storage and quality in Central Morocco. Applied and

751 Environmental Soil Science, $2014 \mathbf{6 5 4 7 9 6}$ DOI 10.1155/2014/654796.

752 Murty D, Kirschbaum MUF, Mcmurtrie RE, Mcgilvray H. 2002. Dose conversion of forest

753 to agricultural land change soil carbon and nitrogen? A review of the literature. Global

754 Change Biology 8: 105e123 DOI 10.1046/j.1354-1013.2001.00459.x

755 Navarrete-Segueda A, Martínez-Ramos M, Ibarra-Manríquez G, Vázquez-Selem L, Siebe

756 C. 2018. Variation of main terrestrial carbon stocks at the landscape-scale are shaped by soil

757 in a tropical rainforest. Geoderma 313: 57-68 DOI 10.1016/j.geoderma.2017.10.023.

758 Osorio K, Haas U, MacMillan K. 2011. Planeación para la conservación de la biodiversidad

759 terrestre en Méxicoretos en un país megadiverso (No. 333.9516 P53).

760 Oueslati I, Allamano P, Bonifacio E, Claps P. 2013. Vegetation and topographic control on

761 spatial variability of soil organic carbon. Pedosphere 23: 48-58 DOI 10.1016/S1002-

$762 \quad 0160(12) 60079-4$

763 Pan JJ, Zhang TL, Zhao QG. 2005. Dynamics of soil erosion in Xingguo County, China,

764 determined using remote sensing and GIS. Pedosphere 15: 356-362.

765 Pan Y, Birdsey RA, Fang J, Houghton R, Kauppi PE, Kurz WA, Phillips OL, Shvidenko A,

766 Lewis SL, Canadell JG, Ciais P, Jackson RB, Pacala SW, McGuire AD, Piao S,

767 Rautiainen A, Sitch S, Hayes D. 2011. A large and persistent carbon sink in the world's

768 forests. Science 333: 988-993 DOI 10.1126/science.1201609.

769 Pèlachs A, Pérez-Obiol R, Soriano JM, Cunill R, Bal MC, García-Codron JC. 2017.

770 Catalan, J., Ninot, J., Aniz, M. (Eds.), High Mountain Conservation in a Changing World. 
771

772

773

774

775

776

777

778

779

780

781

782

783

784

785

786

787

788

789

790

791

792

793

Advances in Global Change Research, vol 62. Springer, Cham, pp. 107-129 DOI 10.1007/978-3-319-55982-7_5.

Perry DA, Oren R, Hart SC. 1994. Forest ecosystems, first ed. The Johns Hopkins University Press. Baltimore, Maryland.

Reddy PP. 2015. Climate resilient agriculture for ensuring food security (Vol. 373), first ed. Springer India, New Delhi.

Reicosky DC. 2016. Long-term effect of moldboard plowing on tillage-induced CO2 loss. Agricultural practices and policies for carbon sequestration in soil. CRC Press 111-122.

Roose EJ, Lal R, Feller C, Barthes B, Stewart BA. 2005. Soil erosion and carbon dynamics, first ed. CRC Press, Boca Raton.

Saha R, Chaudhary RS, Somasundaram J. 2012. Soil health management under hill agroecosystem of North East India. Applied and Environmental Soil Science, 2012696174 DOI 10.1155/2012/696174.

Sarmadian F, Ali K, Antonia O, Ghavamoddin Z, Hossein J. 2014. Mapping of spatial variability of soil organic carbon based on radial basis functions method. ProEnvironment 7: 3-9.

Scharlemann JP, Tanner EV, Hiederer R, Kapos V. 2014. Global soil carbon: understanding and managing the largest terrestrial carbon pool. Carbon Management 5: 81-91 DOI $10.4155 / \mathrm{cmt} .13 .77$.

Scull P, Franklin J, Chadwick OA, McArthur D. 2003. Predictive soil mapping: a review. Progress in Physical Geography 27: 171-197 DOI 10.1191/0309133303pp366ra.

Sedjo RA, Sohngen B, Riddle A. 2015. Land use change, carbon, and bioenergy reconsidered. Climate Change Economics 6: 1550002 DOI 10.1142/S2010007815500025. 
794 Segnini A, Posadas A, Quiroz R, Milori DMBP, Vaz CMP, Martin-Neto L. 2011. Soil

795 carbon stocks and stability across an altitudinal gradient in southern Peru. Journal of Soil and

796 Water Conservation 66: 213-220 DOI 10.2489/jswc.66.4.213.

797 SEMARNAT. 2013. Programa de Manejo Parque Nacional La Montaña Malinche o

798 Matlalcuéyatl D. R. C Secretaría de Medio Ambiente y Recursos Naturales.

799 Shah S, Venkatramanan V. 2009. Agriculture Management practices in relation to soil carbon 800 sequestration: A review. Agricultural Reviews 30: 301-306.

801 Signor D, Deon MDI, Camargo PBD, Cerri CEP. 2018. Quantity and quality of soil organic 802 matter as a sustainability index under different land uses in Eastern Amazon. Scientia 803 Agricola 75: 225-232 DOI 10.1590/1678-992x-2016-0089.

804 Steinfeld H, Gerber P, Wassenaar TD, Castel V, de Haan C. 2006. Livestock's long shadow: 805 environmental issues and options. Food \& Agriculture Org.

806 http://www.fao.org/docrep/010/a0701e/a0701e00.HTM (accessed 28 January 2018).

807 Stocker T. 2014. Climate change 2013: the physical science basis: Working Group I

808 contribution to the Fifth assessment report of the Intergovernmental Panel on Climate Change, 809 first ed. Cambridge University Press, Cambridge, United Kingdom and New York, NY, USA.

810 Stumpf F, Keller A, Schmidt K, Mayr A, Gubler A, Schaepman M. 2018. Spatio-temporal

811 land use dynamics and soil organic carbon in Swiss agroecosystems. Agriculture, Ecosystems

812 \& Environment 258: 129-142 DOI 10.1016/j.agee.2018.02.012.

813 Tang X, Xia M, Pérez-Cruzado C, Guan F, Fan S. 2017. Spatial distribution of soil organic 814 carbon stock in Moso bamboo forests in subtropical China. Scientific reports 7: 42640 DOI $815 \quad 10.1038 / \operatorname{srep} 42640$. 
816 Tucker CJ. 1979. Red and photographic infrared linear combinations for monitoring vegetation.

817 Remote Sensing of Environment 8: 127-150 DOI 10.1016/0034-4257(79)90013-0.

818 Tucker CJ, Pinzon JE, Brown ME, Slayback DA, Pak EW, Mahoney R, Vermote EF, El

819 Saleous N. 2005. An extended AVHRR 8-km NDVI data set compatible with MODIS and 820 SPOT Vegetation NDVI data. International Journal of Remote Sensing 26: 4485-4498 DOI $821 \quad 10.1080 / 01431160500168686$.

822 Tucker CJ, Sellers PJ. 1986. Satellite remote sensing of primary production. International 823 Journal of Remote Sensing 7: 1395-1416 DOI 10.1080/01431168608948944.

824 USGS Global Visualization Viewer (GloVis), https://glovis.usgs.gov (accessed 05 February 825 2018).

826 Valtera M, Šamonil P. 2018. Soil organic carbon stocks and related soil properties in a primary 827 Picea abies (L.) Karst. volcanic-mountain forest. CATENA 165: 217-227

828 DOI 10.1016/j.catena.2018.01.034.

829 van Kuijk M, Anten NP, Oomen RJ, Schieving F. 2014. Stimulating seedling growth in early 830 stages of secondary forest succession: a modelling approach to guide tree liberation. Frontiers 831 in Plant Science 5: 345 DOI 10.3389/fpls.2014.00345.

832 Vargas R, Allen MF, Allen EB. 2008. Biomass and carbon accumulation in a fire 833 chronosequence of a seasonally dry tropical forest. Global Change Biology 14: 109-124 DOI $834 \quad 10.1111 / \mathrm{j} .1365-2486.2007 .01462 . x$.

835 Vauclin M, Vieira SR, Vachaud G, Nielsen DR. 1983. The use of cokriging with limited field 836 soil observations. Soil Science Society of America Journal 47: 175-184 DOI 837 10.2136/sssaj1983.03615995004700020001x. 
838 Wang S, Huang M, Shao X, Mickler RA, Li K, Ji J. 2004. Vertical distribution of soil organic 839 carbon in China. Environmental Management 33: S200-S209 DOI 10.1007/s00267-003-9130-

840 5.

841 Wang YQ, Shao MA. 2013. Spatial variability of soil physical properties in a region of the Loess Plateau of PR China subject to wind and water erosion. Land Degradation \& Development 24: 296-304 DOI 10.1002/ldr.1128.

Watson DF, Philip GM. 1985. A refinement of inverse distance weighted interpolation. Geoprocessing 2: 315-327.

Wei JB, Xiao DN, Zeng H, Fu YK. 2008. Spatial variability of soil properties in relation to land use and topography in a typical small watershed of the black soil region, northeastern China. Environmental Geology 53: 1663-1672 DOI 10.1007/s00254-007-0773-z.

West TO, Post WM. 2002. Soil organic Carbon sequestration rates by tillage and crop rotation: A global data analysis. Division S-6-Soil \& Water Management \& Conservation. Soil Science Society of America Journal 66: 1930-1946 DOI 10.3334/CDIAC/tcm.002.

Wilson BR, Growns, I, Lemon J. 2008. Land-use effects on soil properties on the northwestern slopes of New South Wales: implications for soil condition assessment. Australian Journal of Soil Research 46: 359-367 DOI 10.1071/SR07231.

Xia X, Yang Z, Xue Y, Shao X, Yu T, Hou Q. 2017. Spatial analysis of land use change effect on soil organic carbon stocks in the eastern regions of China between 1980 and 2000. Geoscience Frontiers 8: 597-603 DOI 10.1016/j.gsf.2016.06.003 African Institute of Mining and Metallurgy 105: 223-228. 
860 Yang Y, Zhu J, Tong X, Wang D. 2009. Spatial pattern characteristics of soil nutrients at the 861 field scale, in: Li, D., Zhao, C. (Eds.), Computer and Computing Technologies in Agriculture.

862 Springer, Berlin, Heidelberg. pp. 125-134 DOI 10.1007/978-1-4419-0209-2_14.

863 Zare-mehrjardi M, Taghizadeh-Mehrjardi R, Akbarzadeh A. 2010. Evaluation of

864 geostatistical techniques for mapping spatial distribution of soil $\mathrm{pH}$, salinity and plant

865 cover affected by environmental factors in Southern Iran. Notulae Scientia Biologicae 2:

$866 \quad 92-103$ DOI $10.15835 /$ nsb244997.

867 Zhang H, Zhuang S, Qian H, Wang F, Ji H. 2015. Spatial variability of the topsoil organic

868 carbon in the Moso bamboo forests of southern China in association with soil properties. PloS

869 One 10: e0119175 DOI 10.1371/journal.pone.0119175.

870

871

Zhang S, Huang Y, Shen C, Ye H, Du Y. 2012. Spatial prediction of soil organic matter using terrain indices and categorical variables as auxiliary information. Geoderma 171-172: 35-43

872 DOI 10.1016/j.geoderma.2011.07.012.

873 Zhang Z, Yu D, Shi X, Weindorf DC, Sun Y, Wang H, Zhao Y. 2011. Effects of prediction 874 methods for detecting the temporal evolution of soil organic carbon in the Hilly Red Soil 875 carbon in the cultivated soil layer of dry land in the South-Western Yunnan Plateau, China. Journal of Mountain Science 14: 2484-2497

879

DOI 10.1007/s11629-016-4314-7.

Zhou P, Luukkanen O, Tokola T, Nieminen J. 2008. Effect of vegetation cover on soil erosion 881 in a mountainous watershed. CATENA 75: $319-325$ 


\author{
883 Zimmermann M, Meir P, Silman MR, Fedders A, Gibbon A, Malhi Y, Urrego DH, Bush \\ 884 MB, Feeley KJ, Garcia KC, Dargie GC, Farfan WR, Goetz BP, Johnson WT, Kline KM, \\ 885 Modi AT, Rurau NMQ, Staudt BT, Zamora F. 2010. No differences in soil carbon stocks \\ 886 across the tree line in the Peruvian Andes. Ecosystems 13: 62-74 \\ 887 DOI 10.1007/s10021-009-9300-2.
}


890

891

892

893

894

895

896

897

898

899

900

901

902

903

904

905

906 907 function. points ( ).

Fig. 1. Study area at the national park La Malinche (NPLM).

Fig. 2. Correlation between soil organic carbon content (SOC) in the A horizon and land use in the national park La Malinche (NPLM). (A) Scatter plot with SOC in forest (green diamonds), (B) in seasonal agriculture (yellow squares), and (C) in grassland soil (red triangles), and (D) boxplot with SOCs in the forest, grassland and seasonal agriculture soil.

Fig. 3. Correlation between soil organic carbon content (SOC) in the A horizon and normalized difference vegetation index (NDVI) for the national park La Malinche (NPLM). (A) Map with NDVI at the NPLM and (B) scatter plot with SOC versus NDVI. The sampling

Fig. 4. Spatial distribution of the soil organic carbon content (SOC) in the $O$ and A horizon in the national park La Malinche (NPLM). Maps were generated by three geostatistics methods, i.e. (A) ordinary kriging, (B) empirical Bayesian kriging and (C) cokriging.

Fig. 5. Spatial distribution of soil organic carbon content (SOC) in the $O$ and $A$ horizon of the national park La Malinche (NPLM). Maps were generated by three deterministic methods, i.e. (A) inverse distance weighting, (B) local polynomial interpolation and (C) radial basis 
Figure 1

Study area at the national park La Malinche (NPLM).

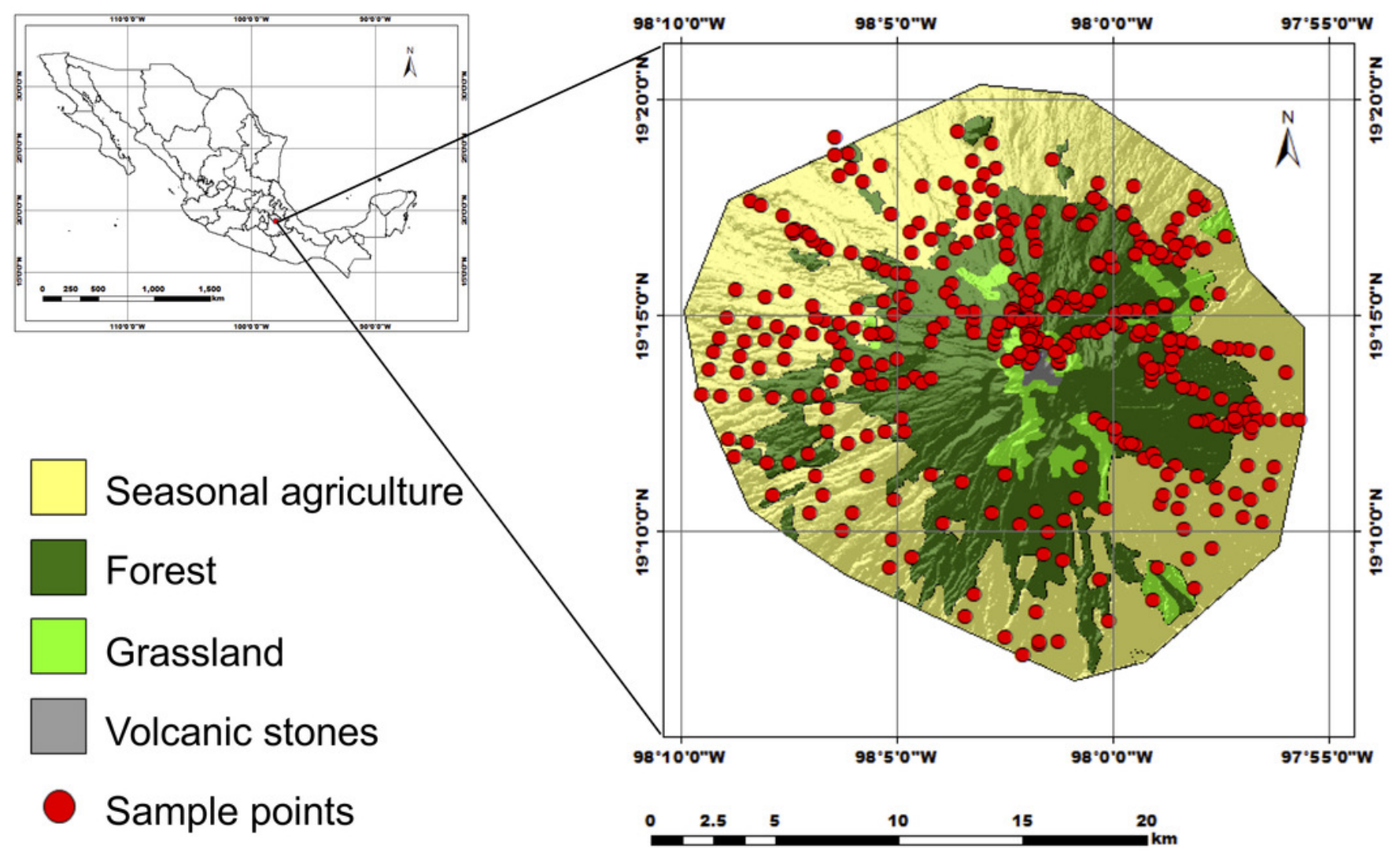


Figure 2

Correlation between soil organic carbon content (SOCs) in the A horizon and land use in the national park La Malinche (NPLM).

(A) Scatter plot with SOC in forest (green diamonds), (B) in seasonal agriculture (yellow squares), and (C) in grassland soil (red triangles), and (D) boxplot with SOCs in the forest, grassland and seasonal agriculture soil. 


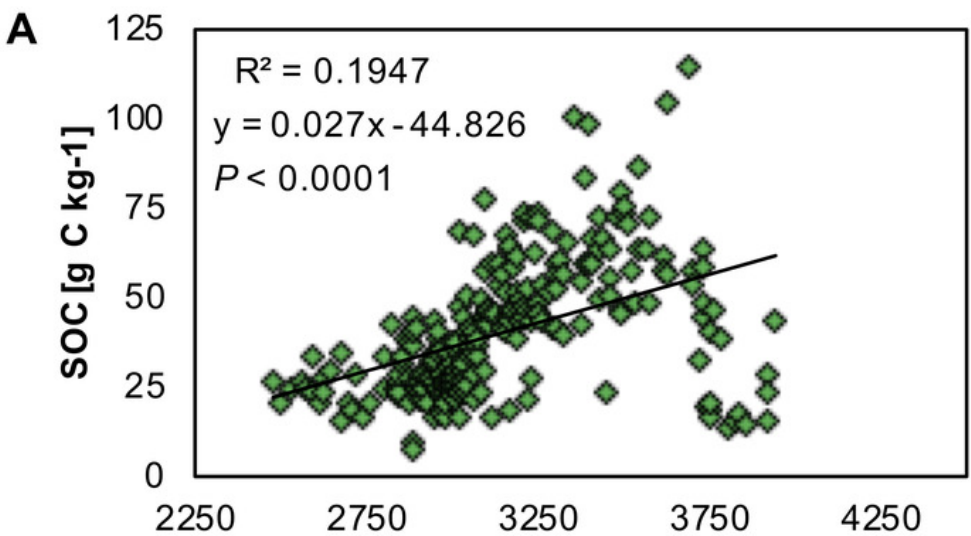

B

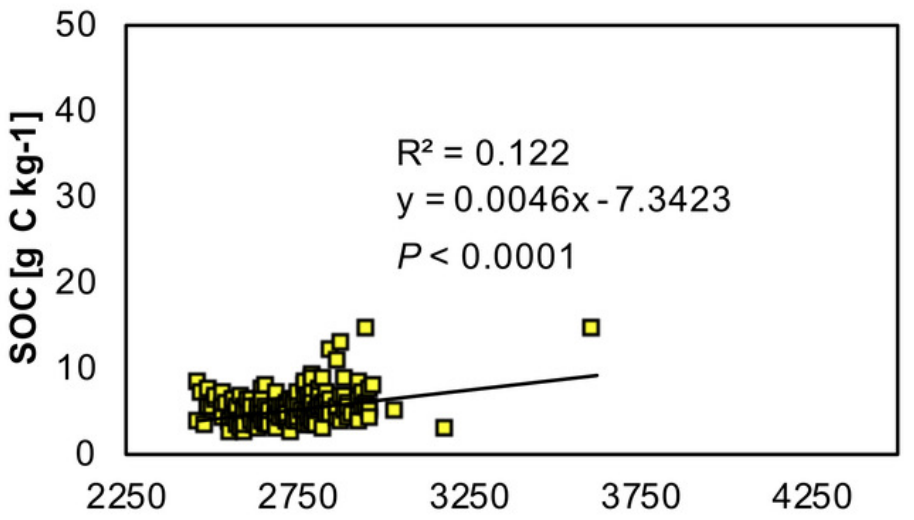

C

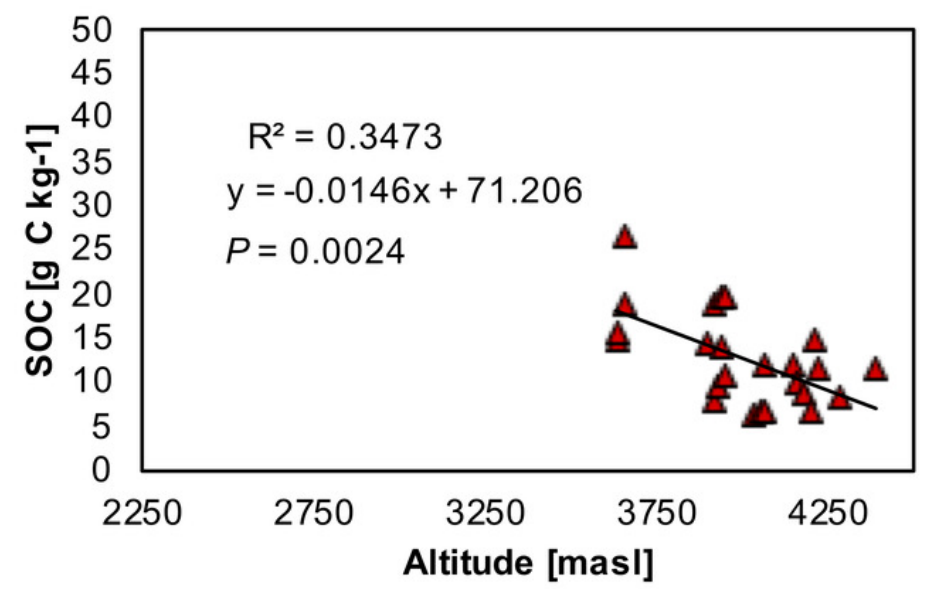

D

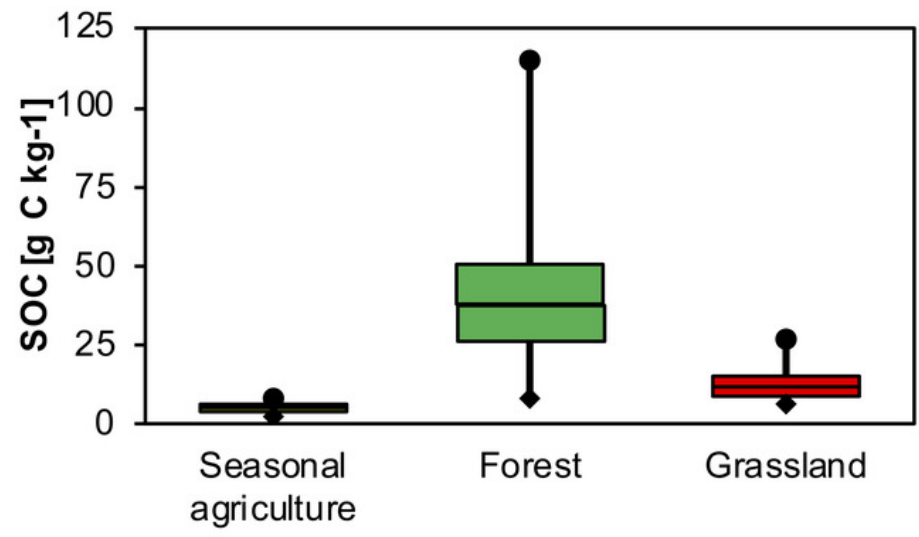

Peer] reviewing PDF | (2019:05:37595:1:1:NEW 28 Aug 2019) 


\section{Figure 3}

Correlation between soil organic carbon content (SOCs) in the A horizon and normalized difference vegetation index (NDVI) for the national park La Malinche (NPLM).

(A) Map of NDVI at the NPLM and (B) scatter plot with SOCs versus NDVI. The sampling points (yellow dots).
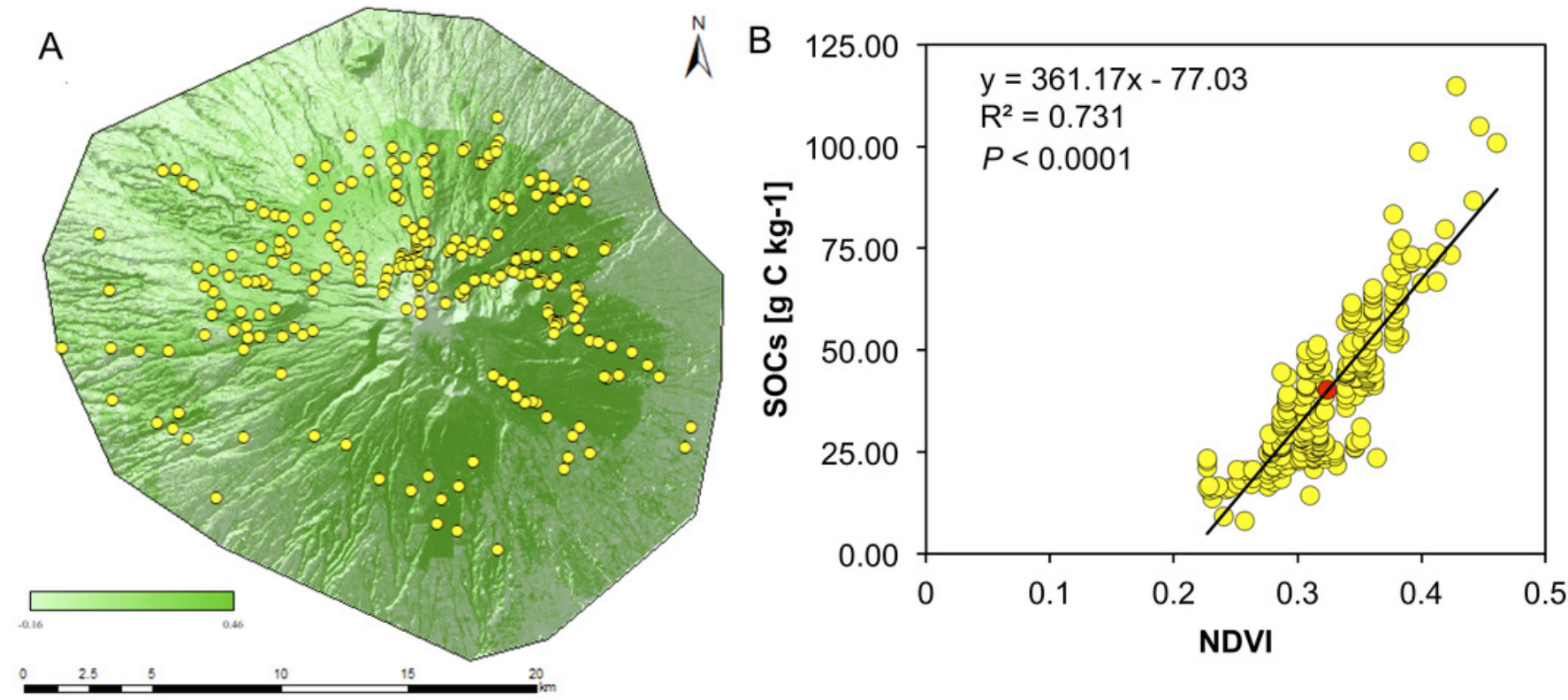


\section{Figure 4}

Spatial distribution of the soil organic carbon content (SOC) in the $\mathrm{O}$ and $\mathrm{A}$ horizon in the national park La Malinche (NPLM).

Maps were generated by three geostatistics methods, i.e. ordinary kriging (OK), cokriging (CK) and empirical Bayesian kriging (EBK).
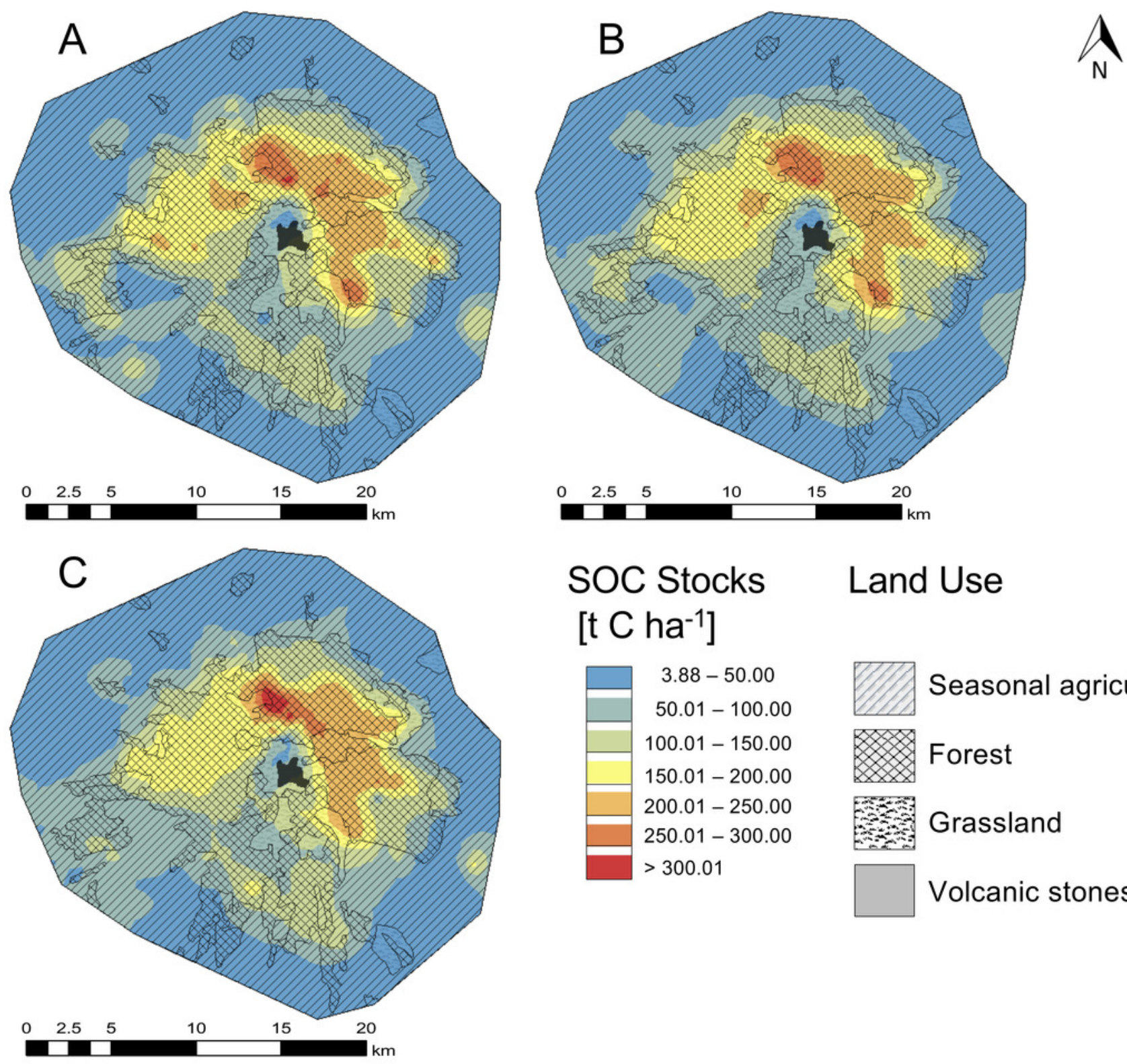

SOC Stocks Land Use [t C ha-1]

\begin{tabular}{|c|}
\multicolumn{1}{|c}{$3.88-50.00$} \\
$50.01-100.00$ \\
$100.01-150.00$ \\
$150.01-200.00$ \\
$200.01-250.00$ \\
$250.01-300.00$ \\
$>>300.01$
\end{tabular}

Seasonal agriculture

Forest

Grassland

Volcanic stones 


\section{Figure 5}

Spatial distribution of soil organic carbon content (SOC) in the $\mathrm{O}$ and $\mathrm{A}$ horizon of the national park La Malinche (NPLM).

Maps were generated by three deterministic methods, i.e. inverse distance weighting (IDW), local polynomial interpolation (LPI) and radial basis function (RBF).
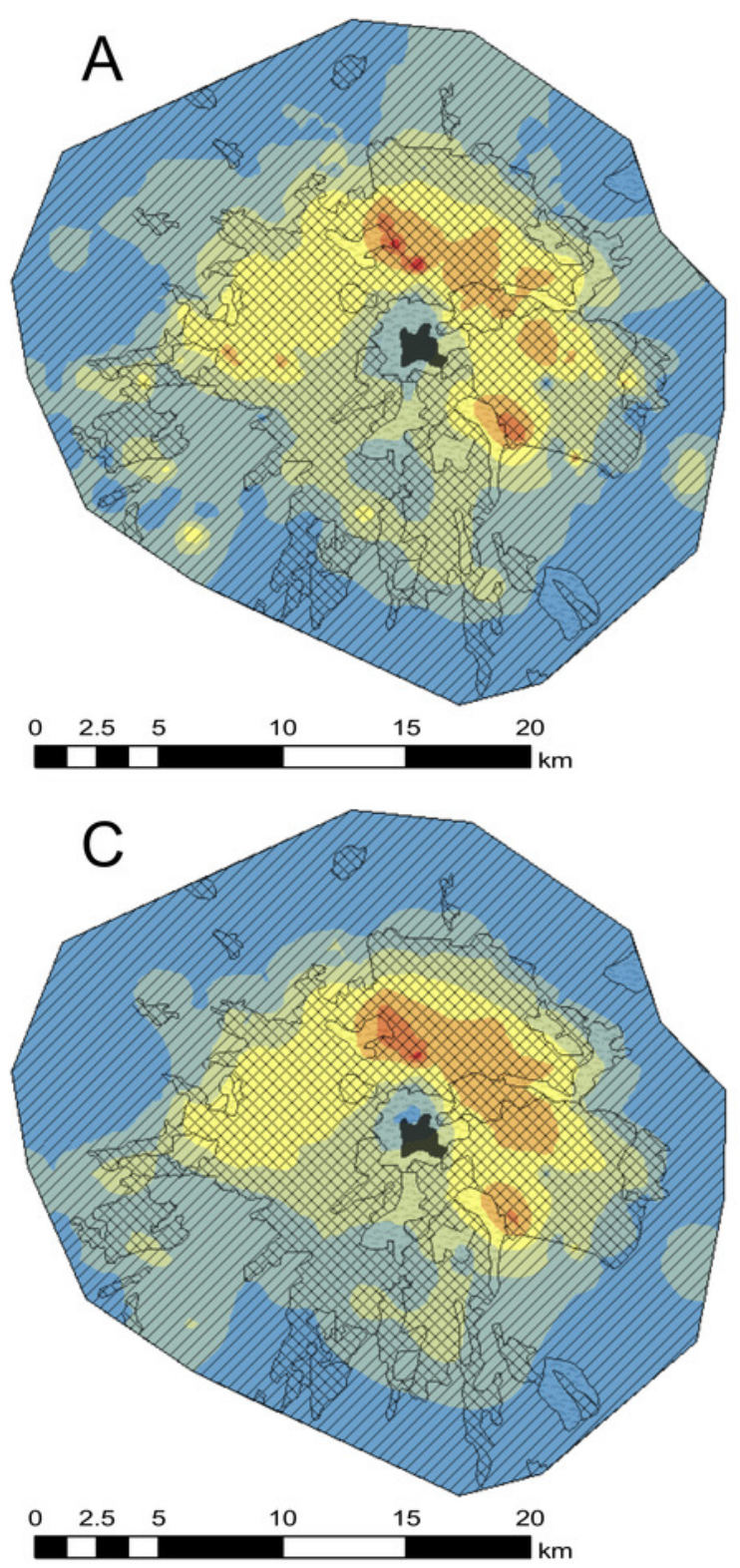

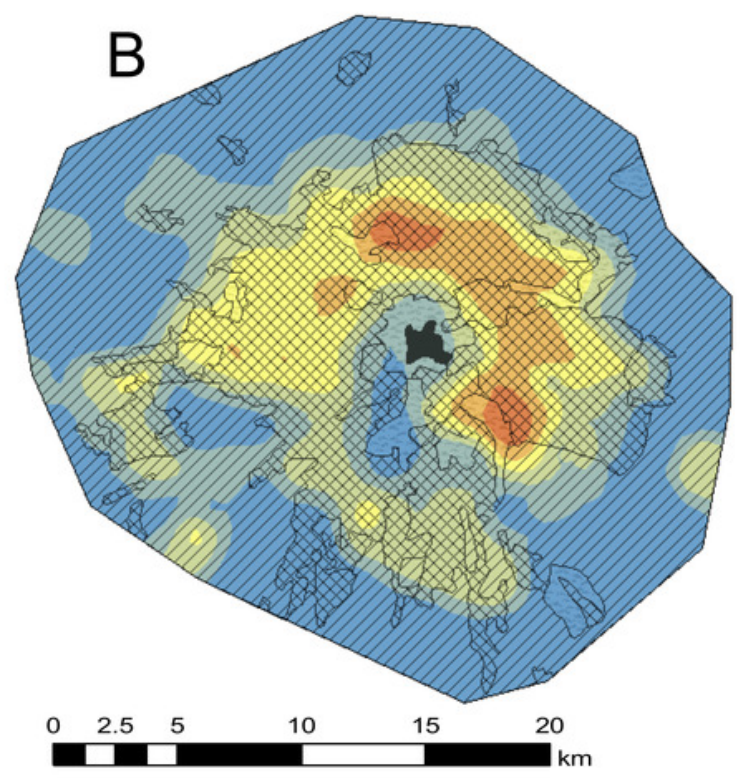

SOC Stocks Land Use [t C ha-1]

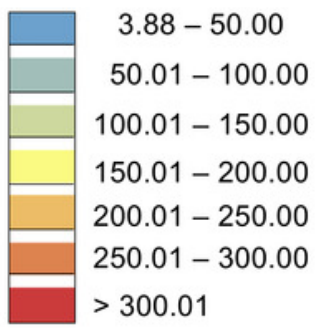

Seasonal agriculture

Forest

Grassland

Volcanic stones 


\section{Table $\mathbf{1}$ (on next page)}

Organic carbon $(\mathrm{SOC})$ content in the $0-15 \mathrm{~cm}$ top soil layer of the national park La Malinche (NPLM). 


\section{Table 1}

2 Organic carbon (SOC) content in the $0-15 \mathrm{~cm}$ top soil layer of the national park La Malinche (NPLM).

Statistic soil organic carbon (SOC) parameters of pedestrian soil layer of the national park La Malinche (NPLM).

\begin{tabular}{|c|c|c|c|c|c|c|c|c|c|c|c|c|c|}
\hline & $\mathbf{N}^{\mathbf{a}}$ & $\underset{\mathbf{b}}{\mathbf{M i n}}$ & $\operatorname{Max}^{c}$ & Range & Mean & Median & $S^{d}$ & $\mathrm{CV}[\%]^{\mathrm{e}}$ & Skewness & Kurtosis & $1^{\circ}$ Quartile & $3^{\circ}$ Quartile & $\underset{\mathbf{f}}{\mathbf{I Q R}}$ \\
\hline & & \multicolumn{6}{|c|}{$\mathrm{SOC}\left[\mathrm{g} \mathrm{kg}^{-1}\right]$} & \multirow[b]{2}{*}{85.66} & \multirow[b]{2}{*}{0.96} & \multirow[b]{2}{*}{0.48} & \multirow[b]{2}{*}{5.48} & \multirow[b]{2}{*}{41.32} & \multirow[b]{2}{*}{35.84} \\
\hline Ecosystem & 440 & 2.33 & 114.87 & 112.54 & 25.81 & 22.76 & $\begin{array}{c}22.1 \\
0\end{array}$ & & & & & & \\
\hline Forest & 253 & 8.02 & 114.87 & 106.85 & 40.31 & 37.81 & $\begin{array}{c}18.5 \\
5\end{array}$ & 45.91 & 0.97 & 1.06 & 25.82 & 50.36 & 24.54 \\
\hline Grassland & 24 & 2.63 & 21.73 & 19.10 & 12.82 & 11.66 & 5.17 & 40.63 & 0.90 & 0.67 & 8.74 & 15.03 & 6.29 \\
\hline Seasonal agriculture & 163 & 2.33 & 14.26 & 11.93 & 5.19 & 4.91 & 1.98 & 38.15 & 1.93 & 5.89 & 3.79 & 5.98 & 2.19 \\
\hline
\end{tabular}

4 Notes:

$5{ }^{\mathrm{a}} \mathrm{N}=$ number of samples, ${ }^{\mathrm{b}} \mathrm{Min}=\operatorname{minimum},{ }^{\mathrm{c}} \mathrm{Max}=\operatorname{maximum},{ }^{\mathrm{d}} \mathrm{SD}=$ standard deviation, ${ }^{\mathrm{e}} \mathrm{CV}=$ coefficient of variation, ${ }^{\mathrm{f}} \mathrm{IQR}=$

6 interquartile range

7 


\section{Table 2 (on next page)}

Organic carbon $(\mathrm{SOC})$ content in the top $0-15 \mathrm{~cm}$ soil in the different ecosystems and altitudes of national park La Malinche (NPLM). 


\section{Table 2}

Organic carbon (SOC) content in the top 0-15 cm soil in the different ecosystems and altitudes of national park La Malinche (NPLM).

Statistic soil organic carbon (SOC) parameters of pedestrian soil layer of the national park La Malinche (NPLM) linked with land use and altitude.

\begin{tabular}{|c|c|c|c|c|c|c|c|c|c|c|c|c|c|}
\hline $\begin{array}{l}\text { Altitude } \\
\text { [masl] }\end{array}$ & Ecosystem & $\mathbf{N}^{\mathbf{a}}$ & $\operatorname{Min}^{b}$ & $\operatorname{Max}^{c}$ & Range & Mean & Median & $S^{d}$ & $\mathrm{CV}[\%]^{\mathrm{e}}$ & Skewness & $\begin{array}{c}1^{\circ} \\
\text { Quartile }\end{array}$ & $\begin{array}{c}3^{\circ} \\
\text { Quartile }\end{array}$ & IQR $^{\mathrm{f}}$ \\
\hline & & & \multicolumn{6}{|c|}{$\mathrm{SOC}\left[\mathrm{g} \mathrm{kg}^{-1}\right]$} & & & & & \\
\hline $2,200-2,500$ & $\begin{array}{c}\text { Seasonal } \\
\text { agriculture }\end{array}$ & 19 & 3.12 & 12.51 & 9.39 & 6.15 & 5.34 & 2.40 & 38.25 & 1.59 & 5.04 & 6.71 & 1.67 \\
\hline $2,501-3,000$ & $\begin{array}{c}\text { Seasonal } \\
\text { agriculture } \\
\& \\
\text { Forest }\end{array}$ & 217 & 2.33 & 44.32 & 41.99 & 13.24 & 8.13 & 11.64 & 88.01 & 0.93 & 4.32 & 24.03 & 19.71 \\
\hline $3,001-3,500$ & Forest & 132 & 2.81 & 100.82 & 98.01 & 46.90 & 45.52 & 17.50 & 37.31 & 0.28 & 35.10 & 59.14 & 24.04 \\
\hline $3,501-4,000$ & Forest & 48 & 8.02 & 114.87 & 106.85 & 38.42 & 30.75 & 25.85 & 67.19 & 0.98 & 16.42 & 57.23 & 40.81 \\
\hline Over 4,000 & Grassland & 24 & 2.63 & 21.73 & 19.10 & 12.82 & 11.78 & 5.28 & 40.63 & 0.90 & 8.78 & 15.02 & 6.29 \\
\hline
\end{tabular}

4 Notes:

$5{ }^{\mathrm{a}} \mathrm{N}=$ number of samples, ${ }^{\mathrm{b}} \mathrm{Min}=$ minimum, ${ }^{\mathrm{c}} \mathrm{Max}=$ maximum, ${ }^{\mathrm{d}} \mathrm{SD}=$ standard deviation, ${ }^{\mathrm{e}} \mathrm{CV}=$ coefficient of variation, ${ }^{\mathrm{f}} \mathrm{IQR}=$ 6 interquartile range 


\section{Table 3(on next page)}

Soil organic carbon (SOC) stock in the soil of the different ecosystems in the national park La Malinche (NPLM). 


\section{Table 3}

2 Soil organic carbon (SOC) stock in the soil of the different ecosystems in the national park La Malinche (NPLM).

Statistic parameters soil organic carbon (SOC) stock of soil of the national park La Malinche (NPLM) linked with land use.

\begin{tabular}{|c|c|c|c|c|c|c|c|c|c|c|c|}
\hline & $\mathrm{N}^{\mathrm{a}}$ & $\operatorname{Min}^{\mathrm{b}}$ & $\operatorname{Max}^{c}$ & Range & Mean & Median & $\mathrm{SD}^{\mathrm{d}}$ & $\mathrm{CV}[\%]^{\mathrm{e}}$ & $1^{\circ}$ Quartile & $3^{\circ}$ Quartile & $\mathrm{IQR}^{\mathrm{f}}$ \\
\hline & & \multicolumn{6}{|c|}{$\mathrm{SOC}$ stock $[\mathrm{t} \mathrm{C} \mathrm{ha-1]}$} & \multirow[b]{2}{*}{87.30} & \multirow[b]{2}{*}{9.42} & \multirow[b]{2}{*}{70.74} & \multirow[b]{2}{*}{$\begin{array}{c}61.3 \\
2 \\
\end{array}$} \\
\hline Ecosystem & 440 & 3.81 & 196.33 & 192.52 & 44.12 & 38.96 & 38.52 & & & & \\
\hline Forest & 253 & 13.72 & 196.33 & 182.61 & 68.94 & 64.65 & 31.72 & 48.91 & 44.17 & 86.15 & $\begin{array}{c}41.9 \\
8\end{array}$ \\
\hline Grassland & 24 & 10.64 & 45.70 & 35.06 & 21.81 & 19.92 & 9.13 & 41.74 & 14.92 & 25.73 & $\begin{array}{c}10.8 \\
1\end{array}$ \\
\hline Seasonal agriculture & 163 & 3.81 & 24.43 & 20.62 & 8.82 & 8.42 & 3.67 & 40.90 & 6.56 & 10.21 & 3.65 \\
\hline
\end{tabular}

4 Notes:

$5{ }^{\mathrm{a}} \mathrm{N}=$ number of samples, ${ }^{\mathrm{b}} \mathrm{Min}=$ minimum, ${ }^{\mathrm{c}} \mathrm{Max}=\operatorname{maximum},{ }^{\mathrm{d}} \mathrm{SD}=$ standard deviation, ${ }^{\mathrm{e}} \mathrm{CV}=$ coefficient of variation, ${ }^{\mathrm{e}} \mathrm{IQR}=$

6 interquartile range

7 
Table 4 (on next page)

Cross validation of the interpolation methods 


\section{Table 4}

2 Cross validation of the interpolation methods.

Cross validation parameters and efficiency of GIS based method for a spatial distribution of soil organic carbon (SOC) in the national park La Malinche (NPLM).

\begin{tabular}{lllll}
\hline Interpolation method & $\begin{array}{l}\text { Efficiency } \\
\mathrm{R}^{2} \mathrm{a}\end{array}$ & \multicolumn{2}{l}{ Error } \\
\cline { 4 - 5 } $\mathrm{RMSE}^{\mathrm{b}}$ & $\mathrm{ME}^{\mathrm{c}}$ & $\mathrm{MRE}^{\mathrm{d}}$ \\
\hline Cokriging (CK) & 0.875 & 14.534 & -4.370 & 0.103 \\
Ordinary kriging (OK) & 0.869 & 14.259 & -4.282 & 0.101 \\
Empirical Bayes kriging (EBK) & 0.844 & 15.021 & -4.847 & 0.096 \\
Inverse distance weighting (IDW) & 0.852 & 14.157 & -4.367 & 0.108 \\
Local polynomial interpolation (LPI) & 0.827 & 15.288 & -6.283 & 0.095 \\
Radial basis function (RBF) & 0.834 & 15.117 & -4.666 & 0.112 \\
\hline
\end{tabular}

4 Notes:

$5 \quad{ }^{\mathrm{a}} \mathrm{R}^{2}=$ coefficient of determination, ${ }^{\mathrm{b}} \mathrm{RMSE}=$ root mean square error, ${ }^{\mathrm{c}} \mathrm{ME}=$ mean error, ${ }^{\mathrm{d}} \mathrm{MRE}=$ mean relative error 6 